Arkivoc

Free to Authors and Readers
A Platinum Open Access Journal

for Organic Chemistry
Review

DOAJ Seal

\title{
Towards $\alpha, \alpha$-disubstituted amino acids containing vicinal stereocenters via stereoselective transition-metal catalyzed allylation
}

\author{
Crystal P. Chung, Patrick D. Parker, and Vy M. Dong* \\ Department of Chemistry, University of California, Irvine, California 92617, United States \\ Email: dongv@uci.edu
}

This review is dedicated to Peter A. Jacobi in honor of his accomplished career in organic chemistry

Received 06-02-2021

Accepted 07-15-2021

Published on line $08-04-2021$

\section{Abstract}

Designer amino acids find use across many scientific disciplines. The preparation of amino acids bearing acyclic vicinal stereocenters remains a challenge in synthesis. Herein, we highlight transition-metal catalyzed allylations for the stereoselective synthesis of disubstituted $\alpha$-amino acid precursors bearing vicinal stereocenters. Allylation of azlactones, $\alpha$-imino esters, and aldimine esters with dienes and allylic leaving groups are among the most common strategies. These developments provide context for our work featuring the asymmetric addition of $\alpha$-nitroesters to alkynes.

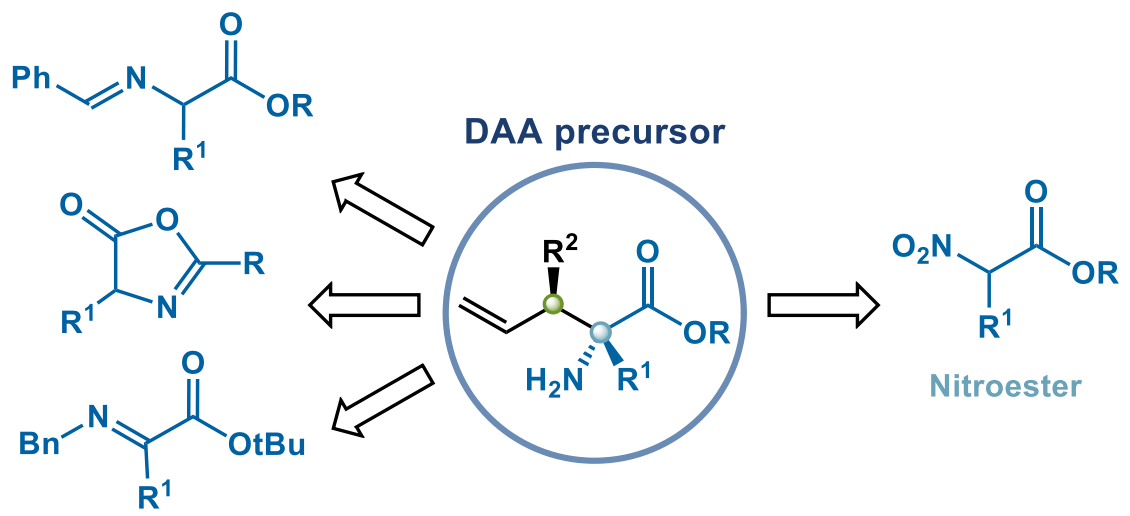

Common nucleophiles

Keywords: $\alpha, \alpha$-disubstituted $\alpha$-amino acids, vicinal stereocenters, stereodivergent, enantioselective 


\section{Table of Contents}

1. Introduction

2. Allylation of Azlactones

3. Synergistic Dual Catalysis

3.1. Allylation of $\alpha$-imino esters

3.2. Allylation of aldimine esters

4. Alkynes as Atom Economical Metal-allyl Precursors

5. Conclusions

\section{Introduction}

Amino acids comprise the backbones of proteins and are fundamental building blocks of living organisms. Consequently, the ability to synthesize unnatural amino acids has enabled development of therapeutics development, ${ }^{1}$ study of protein structure and function, ${ }^{2-4}$ and expansion of the genetic code. ${ }^{5-7}$ Additionally, amino acids have been used as intermediates in total synthesis ${ }^{8,9}$ and as chiral catalysts. ${ }^{10,11}$ More specifically, the incorporation of $\alpha, \alpha$-disubstituted amino acids (DAAs) improves metabolic stabilities and bioactivities for a number of structures (Figure 1). ${ }^{12-14}$ These amino acids can impart unique conformations for folded peptides. ${ }^{15}$<smiles>INC1C=NC(c2c[nH]c3ncccc23)=N1</smiles><smiles>CC[C@H](N)C(=O)NCC(F)(F)F</smiles>

VX-509 decernotinib JAK3 inhibitor<smiles>C[C@](Cc1ccc(O)c(O)c1)(NN)C(=O)O</smiles>

Lodosyn (carbidopa) inhibitor used for Parkinson's disease<smiles>CSCCC(N)C(=O)N[C@]1(C)CS(=O)(=O)[C@@H]2[C@H]1[C@@H]2C(=O)O</smiles>

pomaglumetad methionil prodrug for schizophrenia

Figure 1. Examples of biologically active $\alpha, \alpha$-disubstituted $\alpha$-AA and analogs. ${ }^{12-14}$

Acyclic vicinal stereocenters are important yet challenging motifs to access. Nonetheless, chemists have accessed these scaffolds using strategies such as allylations, conjugate additions, sigmatropic rearrangements, and ring openings. ${ }^{16}$ For allylations, transition-metal catalysis generally offers excellent diastereocontrol, with high enantio- and regioselectivity. ${ }^{16}$ This approach uses allylic carbonates and acetates as surrogates to generate transition-metal- $\pi$-allyl complexes that can be intercepted by a nucleophile. A challenge of allylation involves the control of regioselectivity, determined by which side of the $\pi$-allyl complex is attacked by the nucleophile. ${ }^{17-}$ 20 The "branched" isomer is defined by the attack of the nucleophile on the side with $\mathrm{R}^{2}$, resulting in a product where $\mathrm{R}^{2}$ and the nucleophile are bonded to the same carbon atom (Figure 2). Contrarily, the "linear" isomer is a result of a nucleophilic attack on the $\pi$-allyl complex from the opposing side of $R^{2}$. 

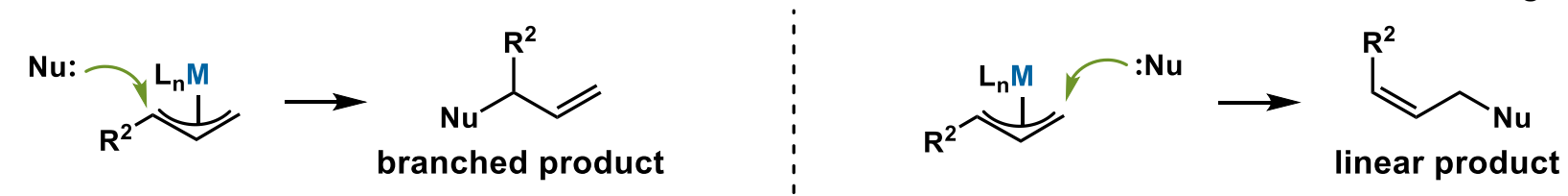

Figure 2. Formation of "branched" versus "linear" isomer.

Herein, we discuss advancements in the use of transition-metal catalyzed allylation for the synthesis of acyclic DAA motifs bearing vicinal stereocenters. This review is organized by the amino acid derived coupling partners: azlactones, $\alpha$-imino esters, and aldimine esters (Figure 3 ). These developments provide context for our work on the addition of $\alpha$-nitroesters to alkynes to access DAA precursors.

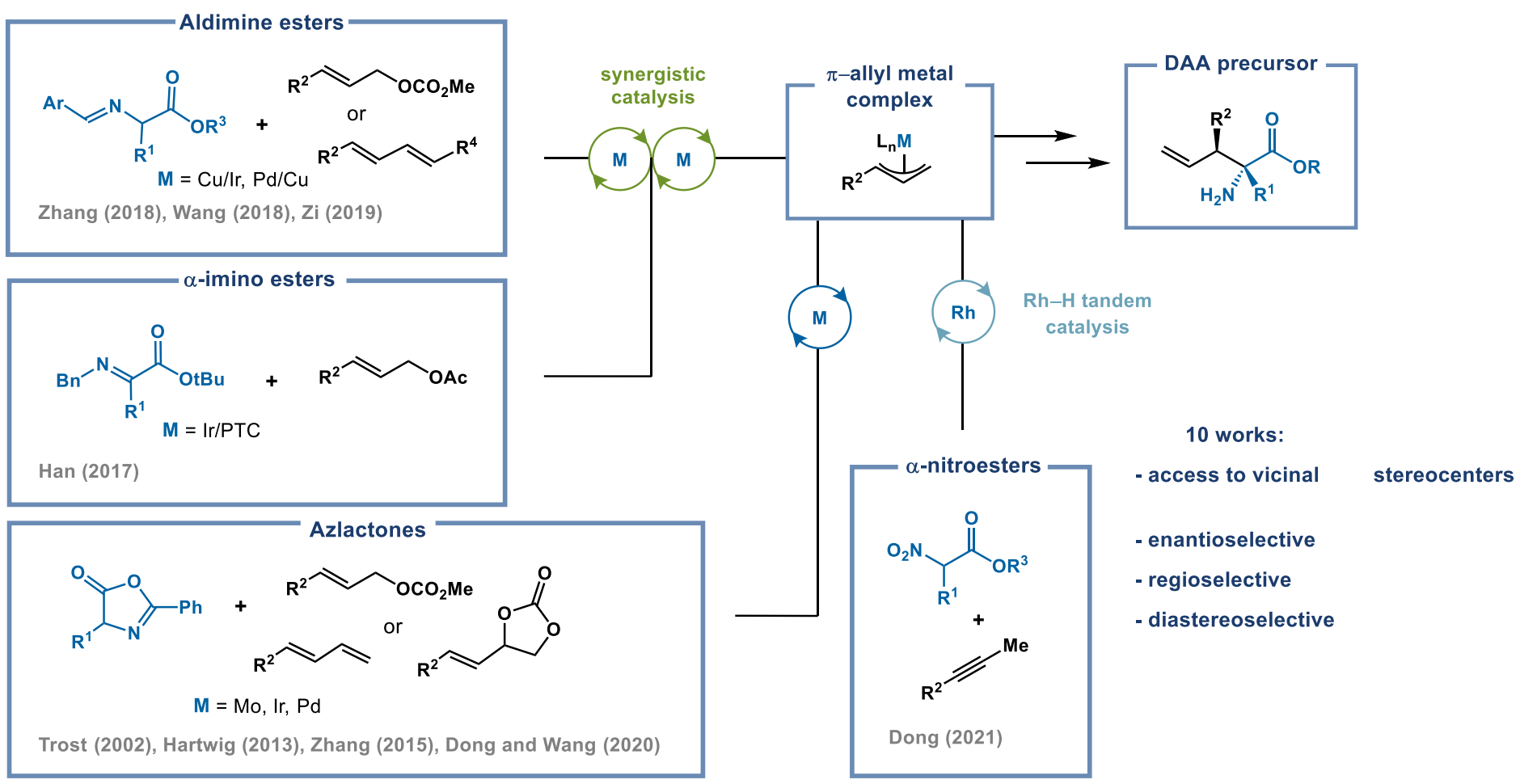

Figure 3. Methods of preparing DAA precursors organized by coupling partner.

\section{Allylation of Azlactones}

Azlactones are the earliest coupling partners used for the synthesis of DAA precursors using a transition-metal catalyzed allylation strategy. These acidic pronucleophiles readily tautomerize and react at the $\mathrm{C} 4$ carbon atom (Figure 4). The first example was reported by Trost which detailed an asymmetric Mo-catalyzed allylation of azlactones using ligand $\mathbf{L 1}{ }^{17}$ This transformation was highly diastereoselective, and the strategic choice of base contributed to a regioselective preference for the branched product 1 . This is followed by in situ hydrolysis to give protected amino ester $\mathbf{2}$. This one-pot protocol led to improved yields and diastereoselectivity compared to earlier multi-step procedures. The substrate scope explored numerous azlactones and aryl-substituted allylic carbonates. A selection of aryl substituents for $R^{2}$ were reported with good results (2a, $\mathbf{2 b}$ ). High branched selectivity was observed for methyl or benzyl $R^{1}$ substituents $(\mathbf{2 a}, \mathbf{2} \mathbf{b}, \mathbf{2 c})$. Substrates containing longer alkyl 
chains, however, suffered from lower regioselectivity (2d, 2e). Altogether, high enantio- and diastereoselectivities were observed. Computational mechanistic studies provided a model for understanding diastereoselectivity. Molecular Mechanics (MM2) calculations suggested that TS1 is approximately 2-10 kcal $\mathrm{mol}^{-1}$ lower in energy than TS2 leading to the observed products.
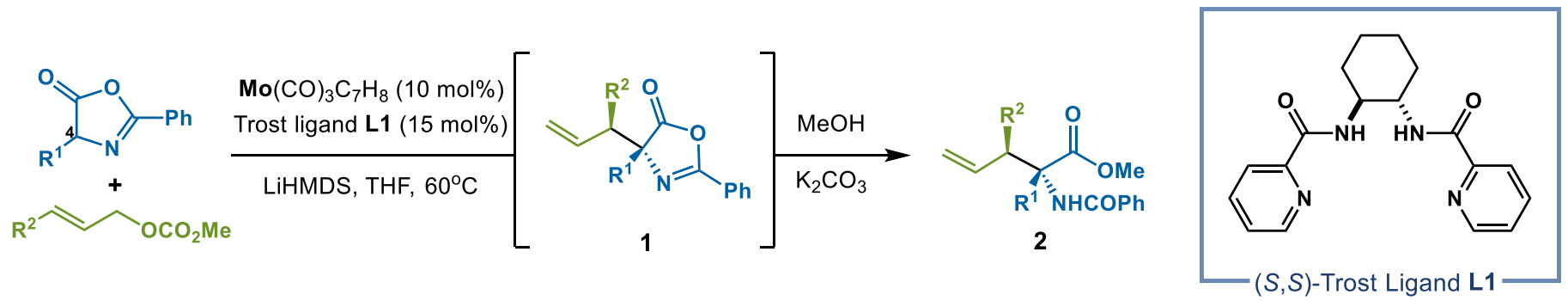

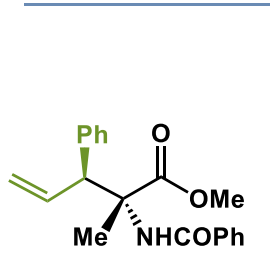

$\mathbf{2 a}, 92 \%$ yield $99 \%$ ee, $97: 3 d r$ linear N.D.

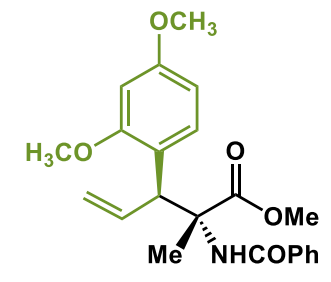

2b, $84 \%$ yield $90 \%$ ee, $>98: 2 d r$ linear N.D.

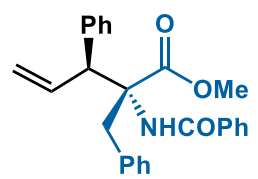

2c, $92 \%$ yield

$96 \%$ ee, $>98: 2 d r$

linear N.D.

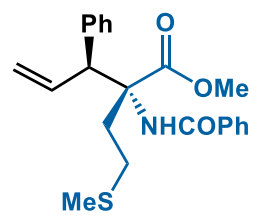

2d, $86 \%$ yield

$92 \%$ ee, $>98: 2 d r$

$6 \%$ linear

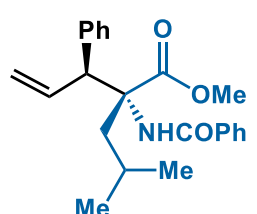

$\mathbf{2 e}, 85 \%$ yield

$96 \%$ ee, $>98: 2 d r$

$5 \%$ linear diasteoromeric transition states

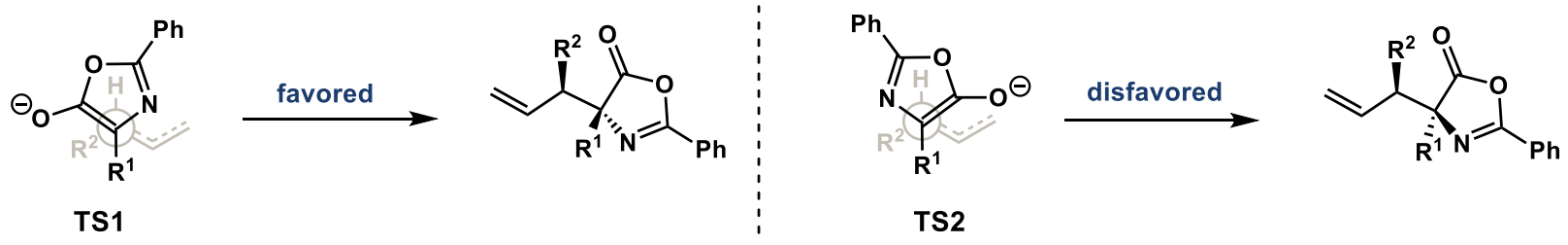

Figure 4. Trost ${ }^{17}$ and co-worker's Mo-catalyzed asymmetric allylic alkylation of azlactones. N.D. = not detected.

Subsequently, Hartwig reported an Ir-catalyzed allylation of azlactones where high diastereo- and enantioselectivities were achieved using O,O,P,N-BINOL ligand L2 for the synthesis of DAA precursors 3 (Figure 5). ${ }^{18}$ The transformation gave high regioselectivities for meta- and para-substituted phenyl $R^{2}$ groups (3a-3d). However, electron-donating substituents were less reactive (3b), and ortho-substituted aryl groups resulted in lower diastereo- and enantioselectivities (3e). This work expands upon the scope of Trost's Mo-catalyzed method by introducing heteroaromatic substituents and dienyl carbonates ( $\mathbf{3} \mathbf{f}$ and $\mathbf{3 g}$ ). Notably, aliphatic allylic carbonates resulted in low diastereoselectivity. As with Trost's method, Hartwig's Ir-catalyzed process favors the branched regioisomer. Furthermore, this method is applicable to azlactones derived from natural amino acids (3h-3j).

Further studies offer insight into the mechanism. Experiments replacing $[\mathrm{Ag}]$ with phosphoric acid $\mathbf{4}$ resulted in the same diastereoselectivity. Meanwhile, experiments without phosphate or phosphoric acid co-catalyst 4 resulted in diminished $d r$, suggesting that the phosphate anion, instead of the silver cation, is responsible for the high diastereoselectivity. These studies also confirm the counterion-assisted allylation via metalacyclic Ir complex 5. 


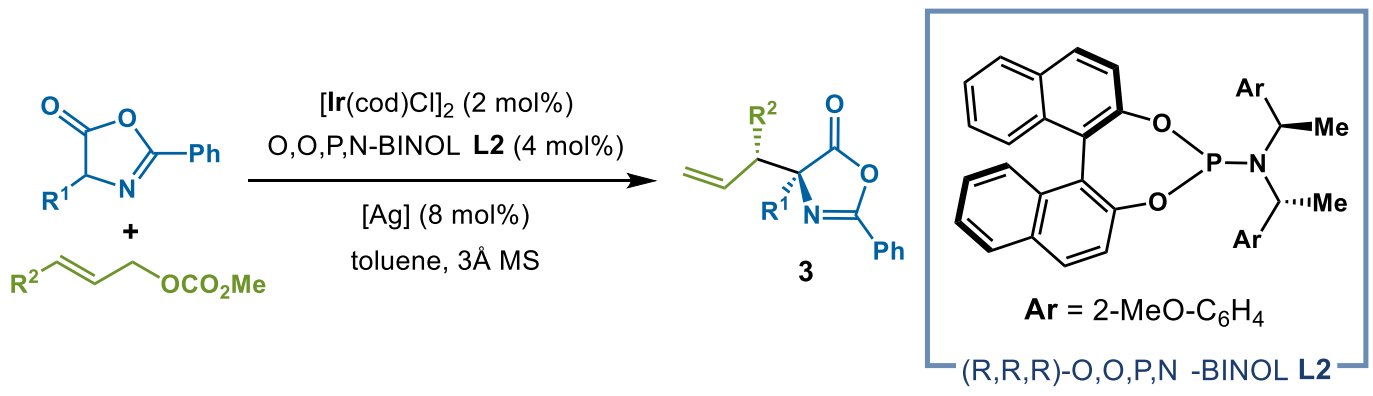

Chung, C. P. et al.

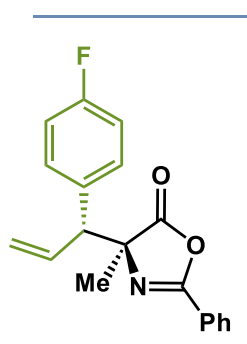

3a, $85 \%$ yield

$98 \%$ ee, $>20: 1 d r$

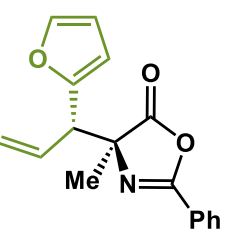

3f, $90 \%$ yield

$98 \%$ ee, $15: 1 d r$

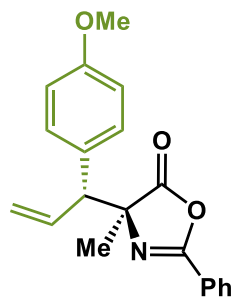

3b, $68 \%$ yield

$>99 \%$ ee, $>20: 1 d r$

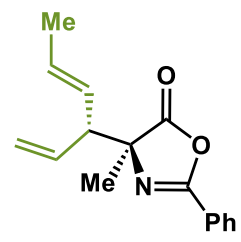

$3 g, 83 \%$ yield

$94 \%$ ee, $14: 1 d r$

selected examples

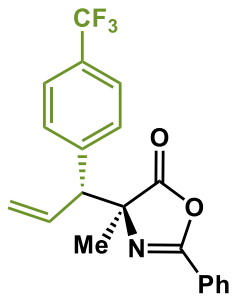

$3 c, 82 \%$ yield

$94 \%$ ee, $>20: 1 d r$

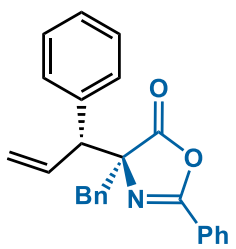

$3 \mathrm{~h}, 83 \%$ yield

$>99 \%$ ee, $12: 1 d r$

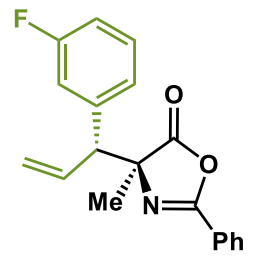

3d, $96 \%$ yield

$>99 \%$ ee, $>20: 1 d r$

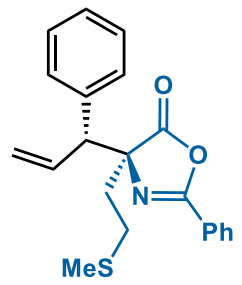

3i, $93 \%$ yield

$98 \%$ ee, $>20: 1 d r$

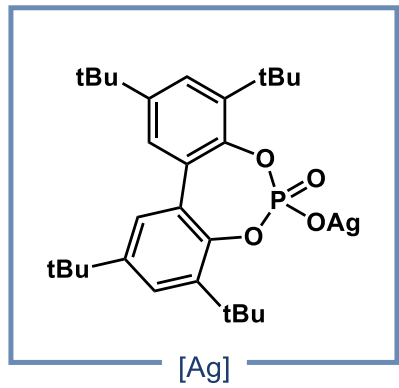

[Ag]

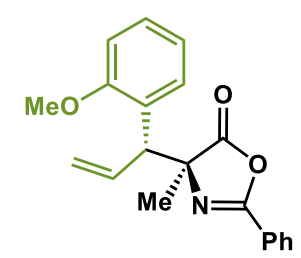

3e, $81 \%$ yield

$80 \%$ ee, $7: 1 d r$

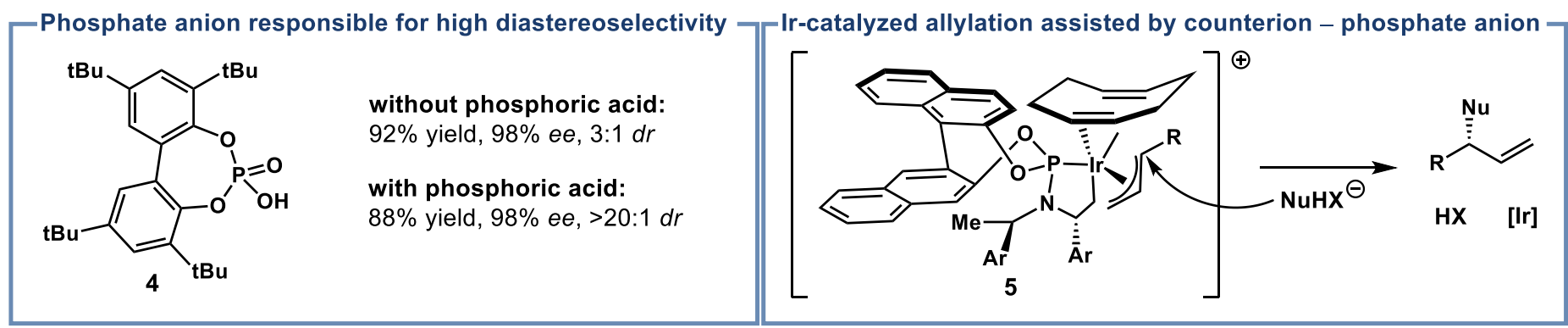

Figure 5. Hartwig ${ }^{18}$ and co-worker's Ir-catalyzed allylation of azlactones with a phosphate counterion.

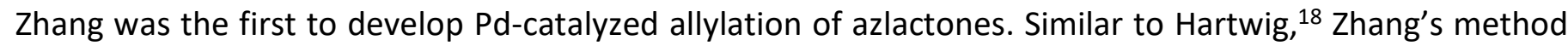
uses O,O,P,N-BINOL ligand L3 to give protected amino acids 6 bearing tethered allylic alcohols (Figure 6). ${ }^{19}$ The enantioselectivity decreases as the sterical hindrance of the $\mathrm{R}^{1}$ substituent increases (6a and $6 \mathbf{b}$ ). Ortho- and para-substituted aryl ethers at $\mathrm{R}^{2}$ were well tolerated giving excellent enantioselectivities (6c-6e). Additionally, heteroaromatic substituents showed great reactivity but modest enantioselectivity (6f). The branched regioselectivity is dependent upon hydrogen-bonding between the incoming azlactone nucleophile and the hydroxyl group of the $\mathrm{Pd}-\pi$-allyl complex (intermediate 7). Removal of the hydroxyl coordinating group via allylic acetate $\mathbf{8}$ leads to a reversal of regioselectivity, as seen in $\mathbf{9}$. Therefore, the strategic choice of a $\mathrm{Pd}-\pi$-allyl precursor (cyclic carbonates or acetates) allows for complementary control of regioselectivity. 


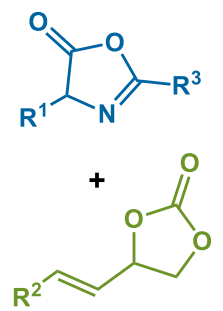

$$
\begin{gathered}
{\left[\mathrm{Pd}\left(\eta^{3}-\mathrm{C}_{3} \mathrm{H}_{5}\right) \mathrm{Cl}\right]_{2}(2.5 \mathrm{~mol} \%)} \\
\mathrm{O}, \mathrm{O}, \mathrm{P}, \mathrm{N}-\mathrm{BINOL} \mathrm{L3}(11 \mathrm{~mol} \%) \\
\mathrm{NaBAr}, \mathrm{Et}_{3} \mathrm{~N}, \mathrm{PhMe}, 0^{\circ} \mathrm{C} \\
\text { then, } \mathrm{NaOMe}, \mathrm{MeOH}
\end{gathered}
$$

\section{O,O,P,N-BINOL L3 (11 mol\%)}

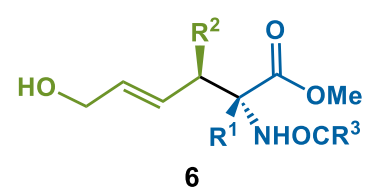

6

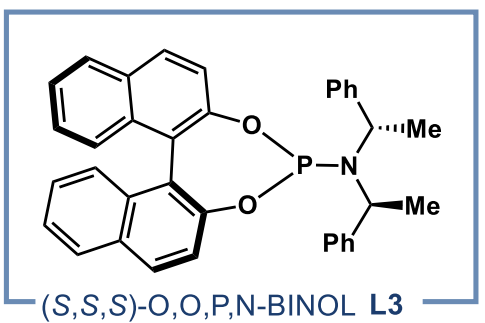

selected examples

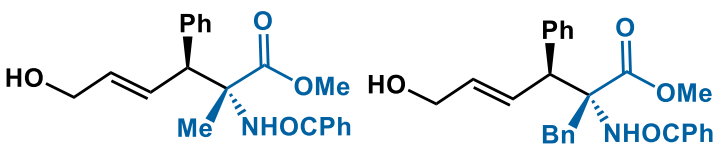

6a, $89 \%$ yield, $96 \%$ ee, $>99: 1 d r$<smiles>COC(=O)[C@](C)(NC(O)c1ccccc1)[C@H](/C=C/CO)Oc1ccccc1C</smiles>

6c, $75 \%$ yield, $89 \%$ ee, $>99: 1 d r$ 6b, $90 \%$ yield, $90 \%$ ee, $>99: 1 d r$

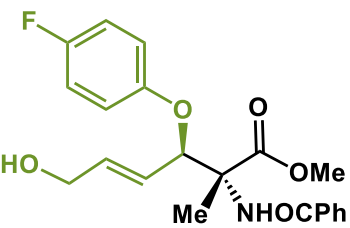

6d, $90 \%$ yield, $99 \%$ ee, $>99: 1 d r$
(N)

6 e, $87 \%$ yield, $99 \%$ ee, $>99: 1 d r$

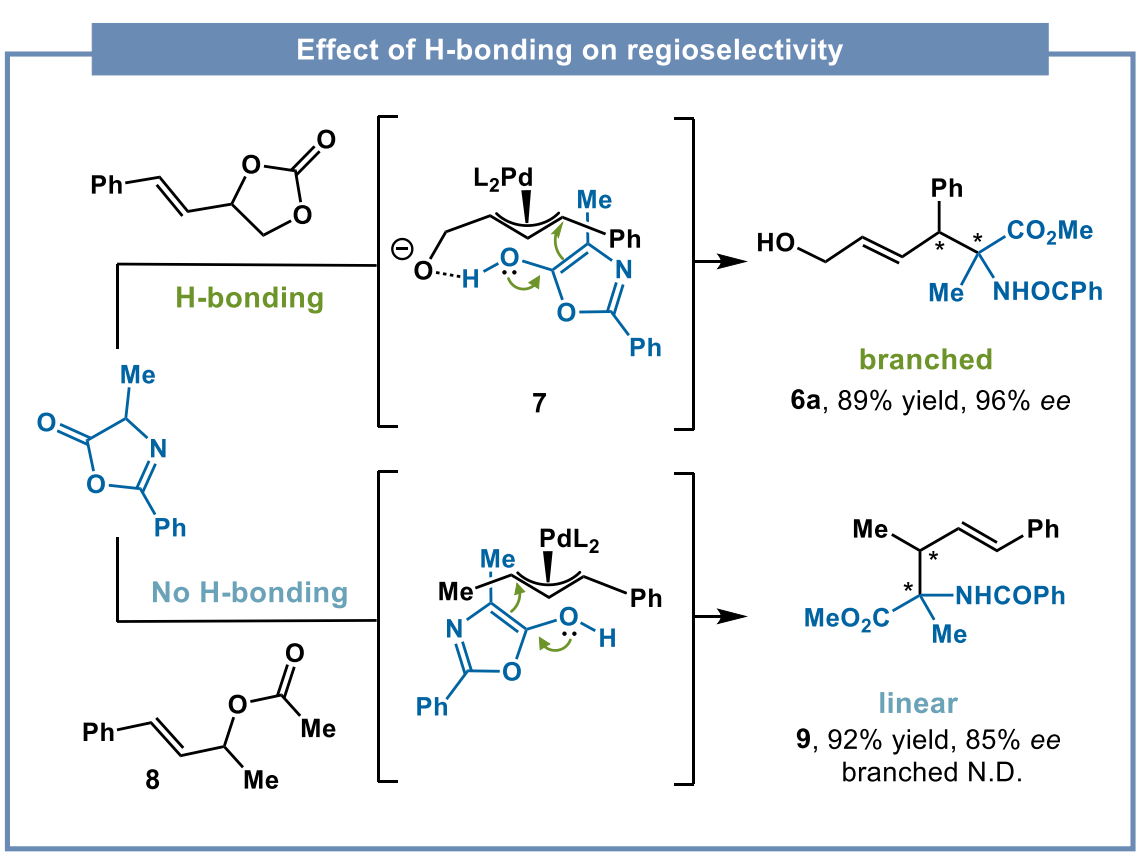

6f, $82 \%$ yield, $67 \%$ ee, $>99: 1 d r$

Figure 6. Zhang ${ }^{19}$ and co-workers' Pd-catalyzed asymmetric allylic alkylation of azlactones.

Other transition-metal $\pi$-allyl precursors include 1,3-dienes. Meek and co-workers reported a Rh-catalyzed hydrofunctionalization of 1,3-dienes with azlactones for the preparation of DAA precursors. ${ }^{21}$ Afterwards, Wang and Dong developed an asymmetric Pd-catalyzed allylation of azlactones with 1,3-dienes using the phosphinooxazoline ligand $\mathbf{L} 4$ (Figure 7). ${ }^{20} \mathrm{~A} \mathrm{Pd}-\mathrm{H}$ is generated by oxidative addition to $\mathrm{HBF}_{4} \cdot \mathrm{Et}_{2} \mathrm{O}$, and the $1,3-$ diene undergoes migratory insertion to generate cationic $\mathrm{Pd}-\pi$-allyl complex 14. Intermediate 14 is then trapped by an azlactone pronucleophile to give DAA precursor 10 . Wang and Dong note that steric hindrance from the tert-butyl group in the ligand likely contributed to the selectivity. 
<smiles>CC(C)(C)C1COC(c2ccccc2P(=O)(O)c2ccccc2)=N1</smiles>

$\mathrm{Ar}=3,5-\left(\mathrm{CF}_{3}\right)_{2} \mathrm{C}_{6} \mathrm{H}_{3}$

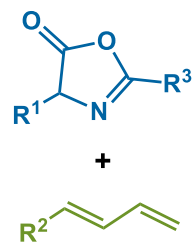

$\mathrm{R}^{2} \curvearrowright$

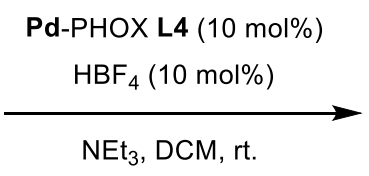

$\mathrm{NEt}_{3}, \mathrm{DCM}, \mathrm{rt}$.

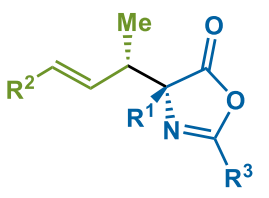

10

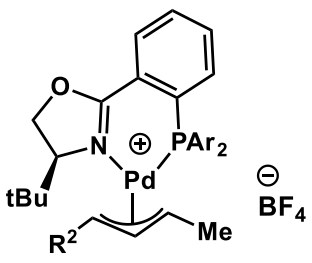

$\mathrm{Ar}=3,5-\left(\mathrm{CF}_{3}\right)_{2} \mathrm{C}_{6} \mathrm{H}_{3}$<smiles>C[C@H](/C=C/c1ccccc1)[C@]1(C)N=C(c2ccccc2)OC1=O</smiles>

$10 a, 92 \%$ yield $95 \%$ ee, $12: 1 d r$

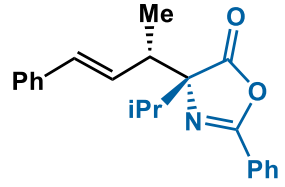

$10 b, 54 \%$ yield

$97 \%$ ee, $>20: 1 d r$

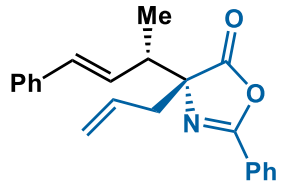

10c, $75 \%$ yield

$99 \%$ ee, $10: 1 d r$

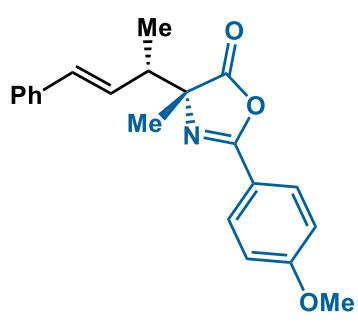

10d, $90 \%$ yield

$98 \%$ ee, $13: 1 d r$

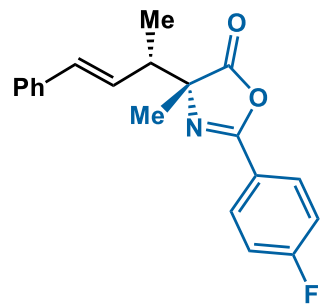

10 e, $87 \%$ yield

$95 \%$ ee, $19: 1 d r$<smiles>CC1=N[C@@](c2ccccc2)([C@H](C)/C=C/c2ccccc2)C(=O)O1</smiles>

10f, $70 \%$ yield $95 \%$ ee, $4: 1 d r$<smiles>[X]c1ccc(/C=C/C(C)[C@]2(C)N=C(c3ccccc3)OC2=O)cc1</smiles>

$\mathbf{X}=\mathrm{Me}$<smiles>C[C@H](/C=C/c1ccccc1F)[C@]1(C)N=C(c2ccccc2)OC1=O</smiles>

$10 i, 75 \%$ yield $94 \%$ ee, $15: 1 d r$<smiles>Cc1cccc(/C=C/[C@@H](C)[C@]2(C)N=C(c3ccccc3)OC2=O)c1</smiles>

10j, 78\% yield $95 \%$ ee, $10: 1 d r$

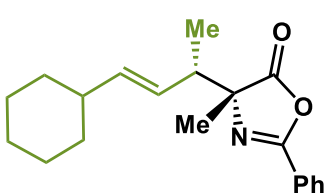

$10 \mathrm{k}, 55 \%$ yield $86 \%$ ee, $4: 1 d r$

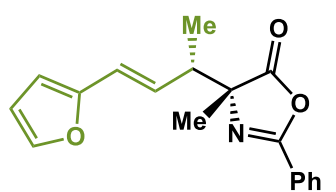

$10 \mathrm{I}, 86 \%$ yield

$97 \%$ ee, $14: 1 d r$

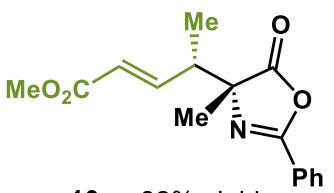

$10 \mathrm{~m}, 82 \%$ yield

$87 \%$ ee $,>20: 1 d r$

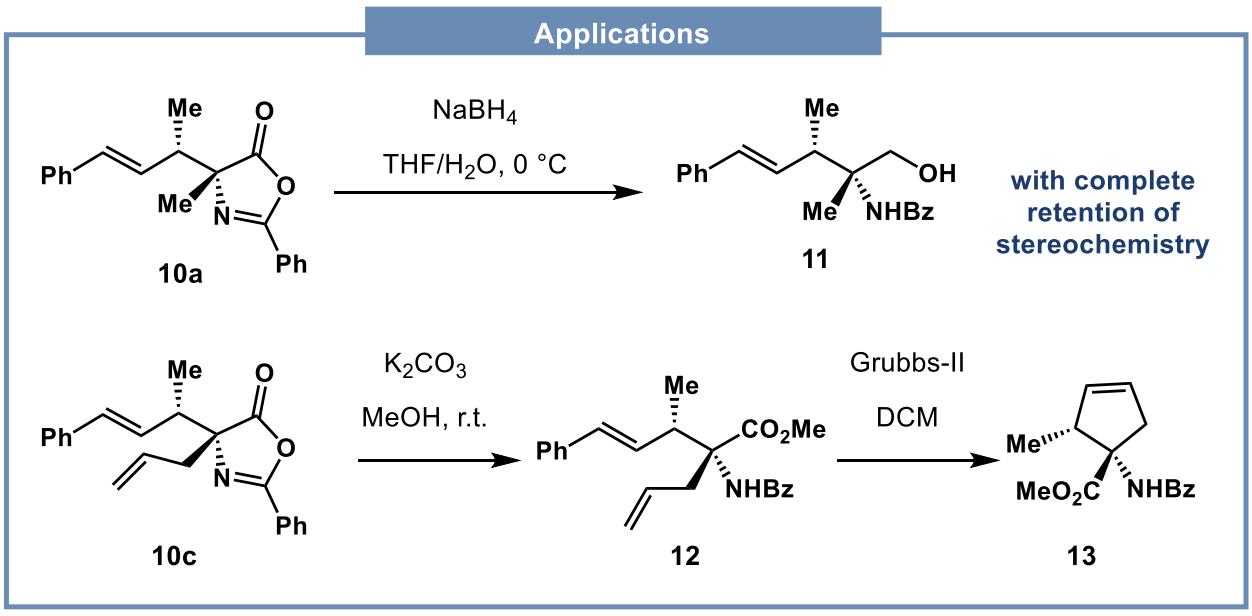

Figure 7. Wang, Dong, ${ }^{20}$ and co-workers' Pd-catalyzed asymmetric hydroalkylation of 1,3-dienes with azlactones.

The substrate scope tolerates a broad array of both aromatic and aliphatic substituents. Compared to substrates with methyl $R^{1}$ substituents (10a), substrates bearing more sterically hindered groups at $R^{1}$ maintained high enantioselectivities (>93\% ee) and diastereoselectivities (>10:1 dr), albeit with lower yields 
(10b). This strategy tolerates olefin side chains giving access to handles for further functionalization (10c) (vide infra). Both electron-rich (10d) and electron-poor (10e) para- aryl $\mathrm{R}^{3}$ substituents showed high reactivity and diastereoselectivity; however, the diastereoselectivity is reduced when aryl $R^{1}$ substituents are introduced (10f). For the scope of 1,3-dienes, both electron-donating $(\mathbf{1 0 g})$ and withdrawing (10h) para-substituted phenyl groups gave higher diastereoselectivities compared to ortho- (10i) and meta-substituents (10j). Alkyl $R^{2}$ substituents (10k) were tolerated with high enantioselectivity but suffered from lower diastereoselectivity. Heteroaromatic furanyl (10I) and electron-withdrawing methyl ester substrates (10m) were reported to maintain good selectivity and yield. Although broad, the scope was limited to terminal 1,3-dienes.

Synthetic applications of these allylated azlactones were demonstrated. Reductive ring opening of 10a gave the $\beta$-amino alcohol 11 with complete retention of stereochemistry. Hydrolysis of allyl-substituted allylation product $10 \mathrm{c}$ with $\mathrm{K}_{2} \mathrm{CO}_{3}$ gave the protected amino ester 12. A ring closing metathesis of 12 with Grubbs-II gave cyclopentene 13. These cyclic intermediates can be used for the synthesis of biologically relevant compounds such as metabotropic receptor antagonists. ${ }^{22}$

\section{Synergistic Dual Catalysis}

The simultaneous activation of two coupling partners with two independent catalysts is known as synergistic catalysis. ${ }^{23}$ This strategy has become a useful tool for the synthesis of complex molecular architectures, ${ }^{24}$ and it has been especially useful in transition-metal catalyzed allylations. When each co-catalyst is chiral, synergistic catalysis can provide divergent control over the relative stereochemistry of two generated vicinal stereocenters. By the simple exchange of a catalyst with its enantiomer, one can access the opposite diastereomer. Herein, we highlight recent advancements in the use of synergistic transition-metal catalysis for the allylation of $\alpha$-imino esters to access DAA motifs.

\subsection{Allylation of $\alpha$-imino esters}

The earliest synergistic approach for the synthesis of DAA precursors was reported by Han. ${ }^{25}$ Here, a chiral Ir catalyst was used along with a phase transfer ammonium co-catalyst to solubilize the in situ generated 2-azaallyl anion 16 (Figure 8). The use of an ammonium co-catalyst was necessary for high yield and enantioselectivity. The solvated anion 16 then attacks the Ir- $\pi$-allyl complex 17 to generate the amino ester 15. This method tolerates a range of aromatic substitutions. High enantio- and diastereoselectivity is achieved with orthosubstituted phenyl groups at the $R^{2}$ position (15a, 15b). In addition, para- (15c, 15f) and meta-substituted (15d) phenyl and naphthalene (15e) substituents are tolerated at the $\mathrm{R}^{1}$ position. Ortho-subsituted aryl nitroesters (not shown) are not tolerated likely due to steric hindrance.

There are many notable advantages offered by Han's report. Contrary to the use of azlactones, dual catalysis provides single-step direct access to the acyclic amino ester motif. Additionally, a wide selection of aryl $\mathrm{R}^{1}$ substituents, which were inaccessible by azlactone methods, are available using synergistic catalysis (vide supra). This expansion of scope allows for the preparation of biologically interesting compounds. ${ }^{26}$ For instance, acylation of $\mathbf{1 5 f}$ followed by cyclization with iodine provides the quaternary proline analogue $\mathbf{1 8}$. These highly substituted proline derivatives are crucial for nucleating secondary structures in peptides. ${ }^{26}$ In addition, deprotection of $\mathbf{1 5 f}$ can be facilitated by TFA to provide the corresponding DAA 19. 

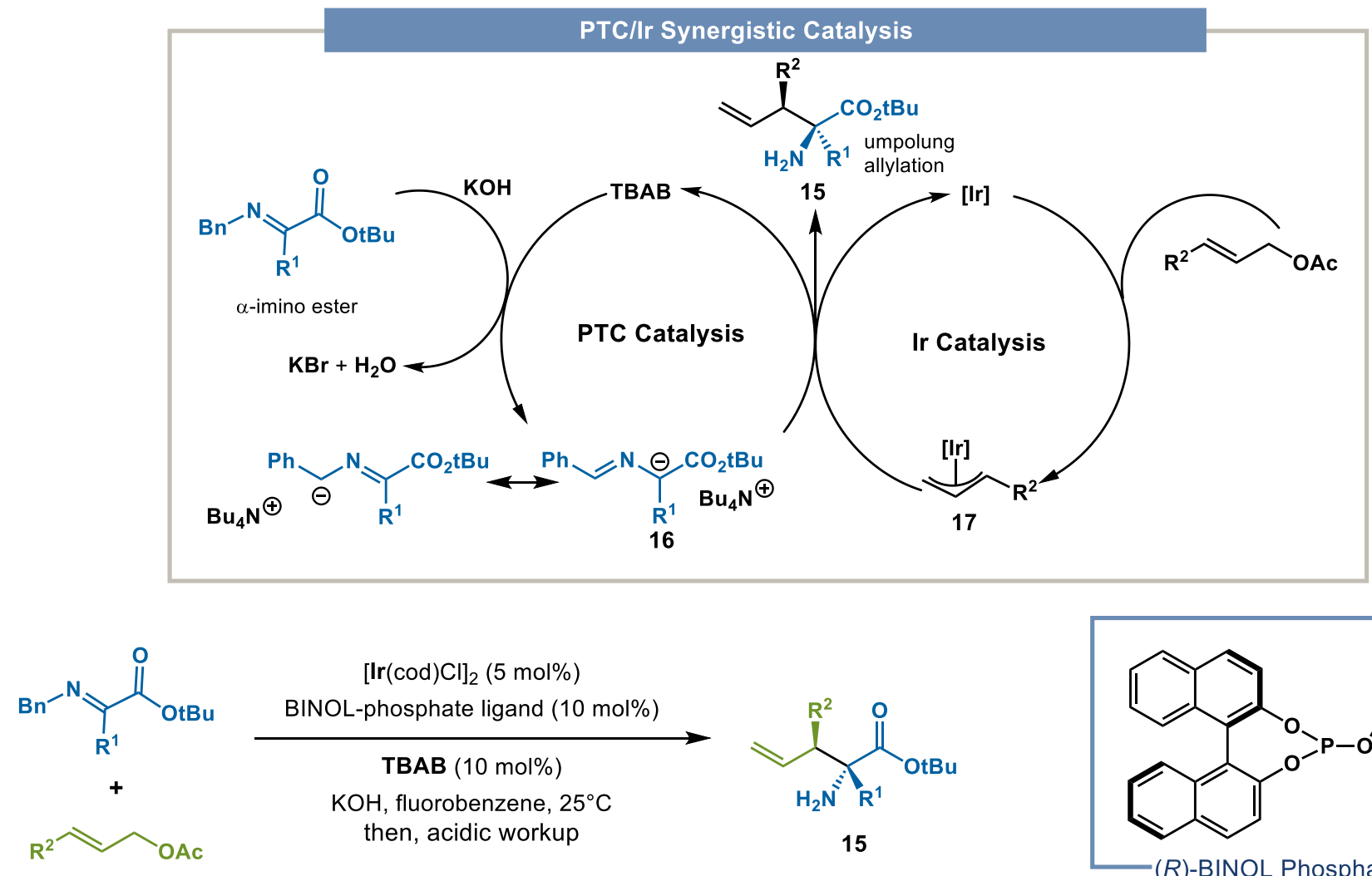

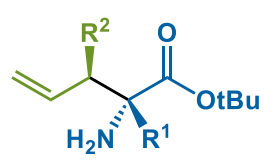

15

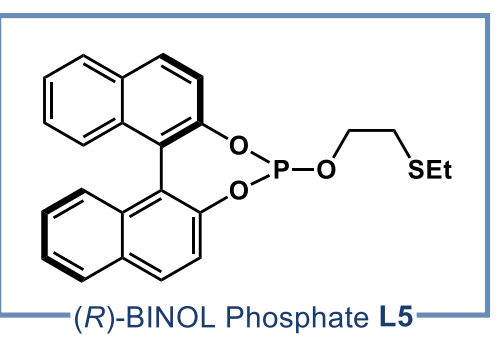

selected examples

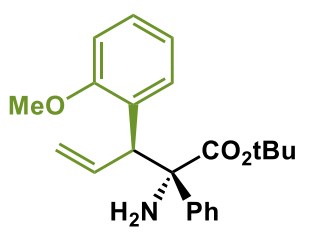

15a, $81 \%$ yield

$92 \%$ ee, $17: 1 d r$

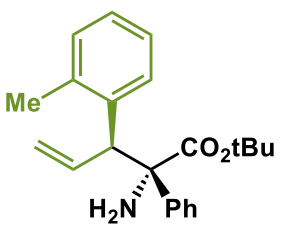

15b, $74 \%$ yield

$90 \%$ ee, $>20: 1 d r$

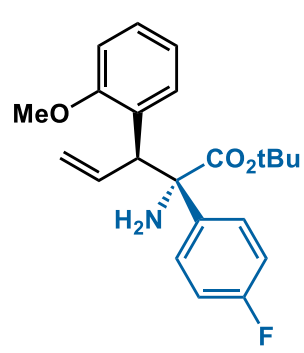

15c, $77 \%$ yield

$88 \%$ ee $,>20: 1 d r$

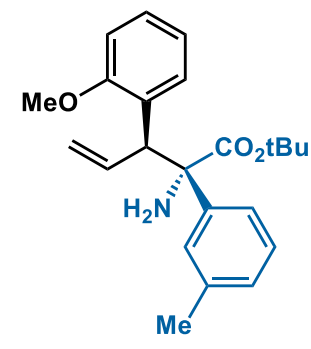

15d, $88 \%$ yield

$92 \%$ ee $,>20: 1 d r$

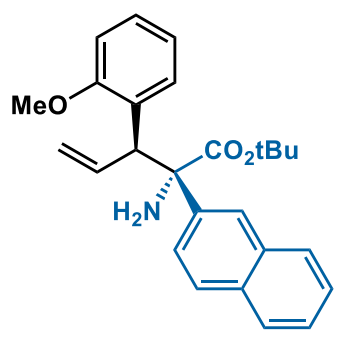

$15 e, 82 \%$ yield

$82 \%$ ee $,>20: 1 d r$

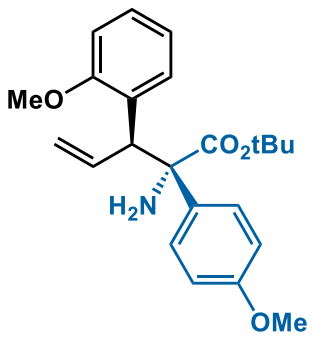

15f, $80 \%$ yield

$96 \%$ ee, $>20: 1 d r$ applications
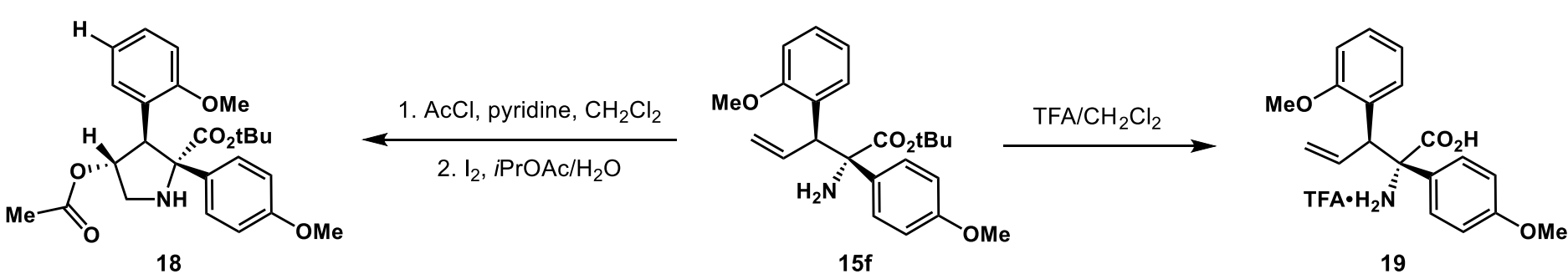

Figure 8. Han ${ }^{25}$ and co-workers' Ir and PTC dual-catalyzed asymmetric umpolung allylation of $\alpha$-imino esters.

\subsection{Allylation of aldimine esters}

Zhang ${ }^{27}$ and Wang ${ }^{28}$ independently reported the first synergistic methods using two transition-metal cocatalysts ( $\mathrm{Cu}$ and $\mathrm{Ir}$ ) to prepare $\alpha$-AAs bearing vicinal stereocenters. By altering the ligand stereochemistry of either complex, all four stereoisomers could be accessed (Figure 9). A Cu catalyst bearing the chiral PHOX ligand 
L6 activates the aldimine ester to form cyclic ylide 20. Meanwhile, an Ir catalyst containing the chiral O,O,P,N ligand $\mathbf{L} \mathbf{3}$ coordinates to the allylic carbonate, generating the $\pi$-allyl complex $\mathbf{2 1}$. Lastly, transition-metal complexes $\mathbf{2 0}$ and $\mathbf{2 1}$ are coupled to generate a new $\mathrm{C}-\mathrm{C}$ bond forming amino ester $\mathbf{2 2}$. Therefore, the Cu catalyst controls the $\alpha$-carbon stereochemistry, and the Ir catalyst controls the $\beta$-carbon's stereochemistry.

\section{Stereodivergent access to all steroisomers}

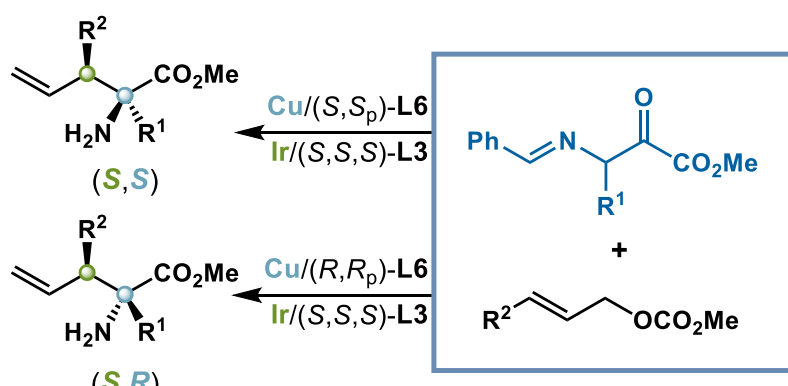

$(S, R)$

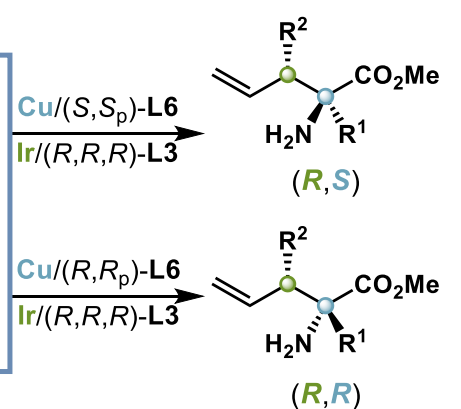

$(R, R, R)-\mathbf{L} 3=$

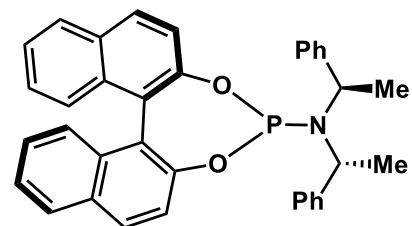

$\left(S, S_{p}\right)$-L6 =

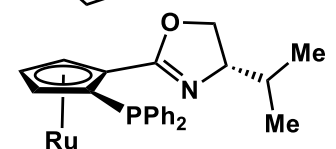

\section{Synergistic dual catalysis}

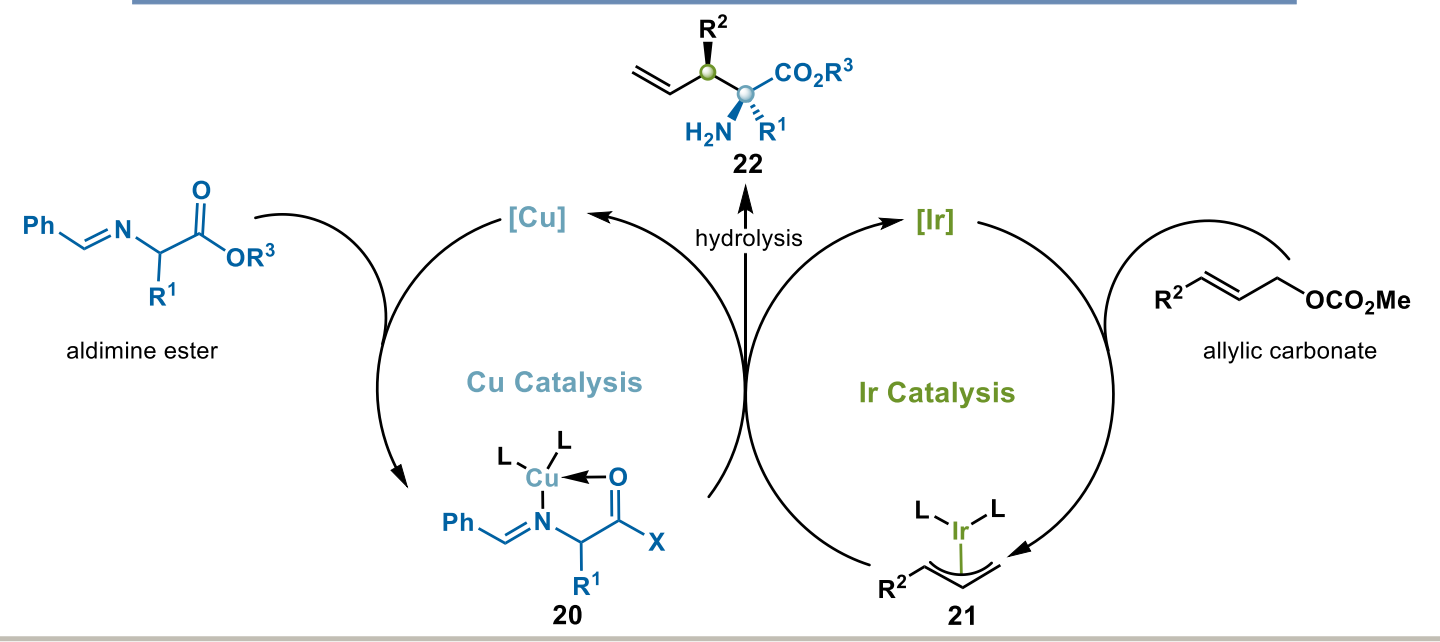

Figure 9. Synergistic dual catalysis allows controlled access to all four stereoisomers (top). Mechanism shows that each metal catalyst controls stereochemistry of one of the vicinal stereocenters (bottom).

The substrate scope of Zhang's study was quite broad. ${ }^{27}$ All stereoisomers of model substrate 23a were accessed in similar yields and selectivities by judicious combinations of the $\mathrm{Cu}$ and Ir catalysts (Figure 10). Electron-donating and electron withdrawing ortho-, meta-, and para-substituted phenyl rings at the $\mathrm{R}^{2}$ position resulted in excellent enantioselectivities and good diastereoselectivities (23b, 23c, 23d, 23e). Heteroaromatic substituents such as indolyl $\mathbf{2 3 f}$ suffered from lower diastereoselectivity. When the aromatic substituent was replaced with a methyl group in $\mathrm{R}^{2}$, the enantioselectivity and diastereoselectivity remained high, but the yield dropped. A variety of aldimine esters were also well tolerated, particularly those with OMe as $\mathrm{X}$. The allylation of $\alpha$-AAs (23g) and dipeptides (23h) were also demonstrated. Stereo-divergent access to two stereoisomers of Gly-L-Leu derivative (23h) was achieved with high diastereoselectivity, while also retaining the configuration of the pre-existing stereocenter. 

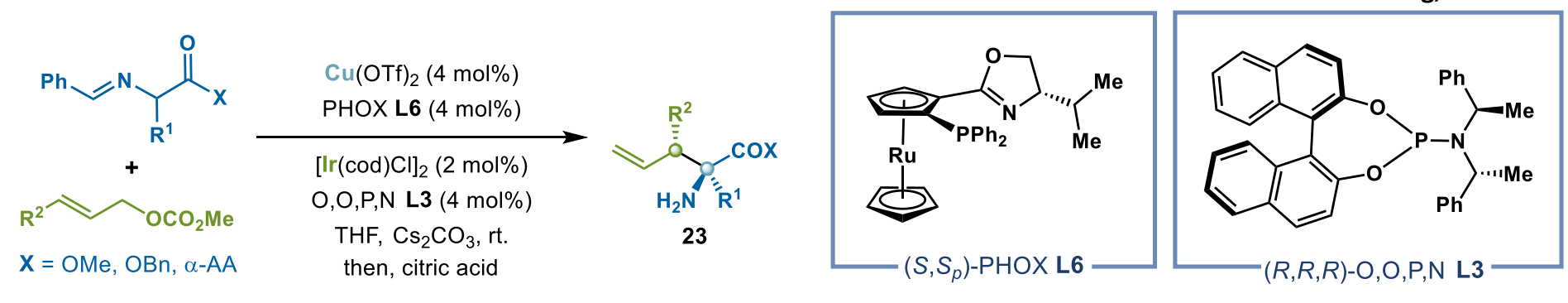

selected examples

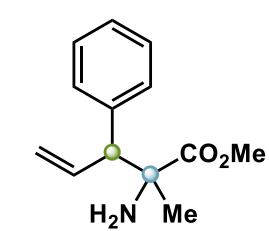

$>99 \%$ ee, $>20: 1 d r$

$(R, S)-23 a: 88 \%$ yield

$(R, R)-23 a: 91 \%$ yield

$(S, S)-23 a: 91 \%$ yield

$(S, R)-23 a: 89 \%$ yield

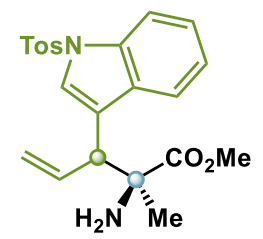

(S,S)-23f: 72\% yield, $94 \%$ ee, $3: 1 d r$

(R,S)-23f: 92\% yield, 99\% ee, 19:1 dr
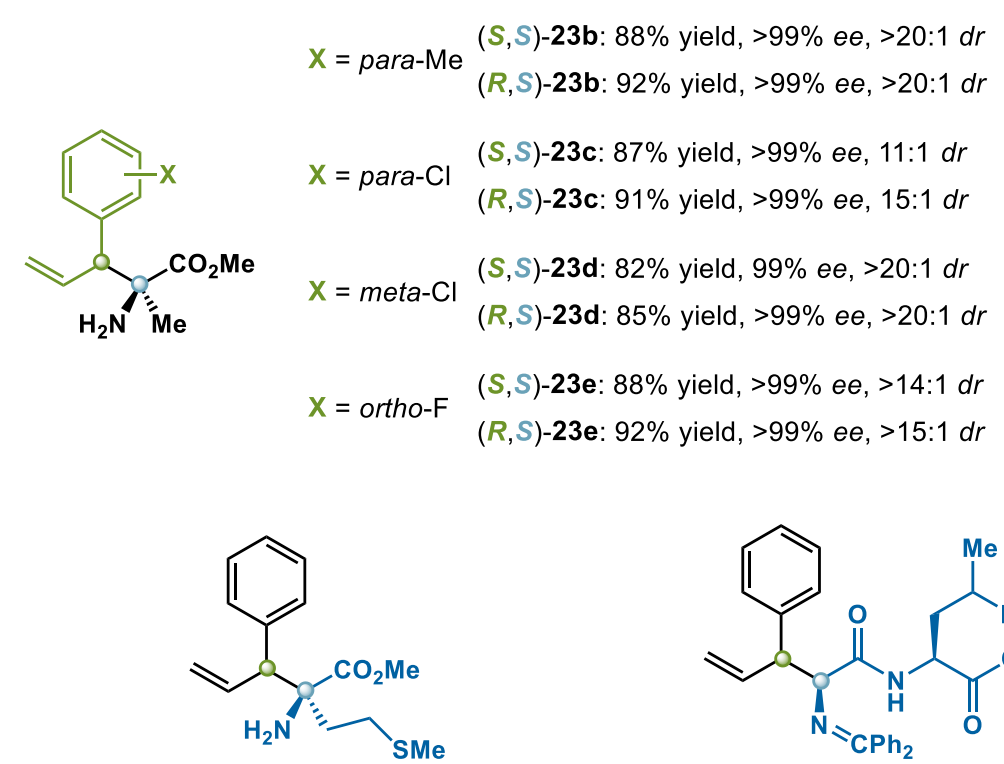

(S,S)-23g: 76\% yield, >99\% ee, 10:1 dr

(R,S)-23g: $72 \%$ yield, $99 \%$ ee, $>20: 1 d r$

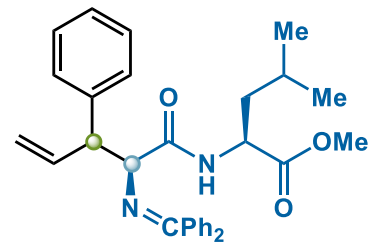

(S,S,S)-23h: $91 \%$ yield, >20:1 dr $(R, S, S)-23 h: 88 \%$ yield, $>20: 1 d r$

Figure 10. Zhang ${ }^{27}$ and co-workers' Ir and Cu dual-catalyzed allylation of aldimine esters.

Similarly, Wang reported an Ir and Cu dual catalyzed allylation of aldimine esters (Figure 11). ${ }^{28}$ The results show improved scope with para-, meta-, and ortho-substituted phenyl allylic carbonates. Notably, para-fluoro substitutions gave higher diastereoselectivity but meta-halogenated rings gave lower selectivities compared to Zhang's work (24b). Observed diastereoselectivity was $>20: 1$ for all reported allylic substrates, including aromatic, furyl, thienyl, and methyl (24a) for $\mathrm{R}^{2}$. The only exceptions were 2-thiazolyl and para- $\mathrm{Cl}-\mathrm{C}_{6} \mathrm{H}_{4}, w_{h i c h}$ gave 7:1 dr and 14:1 dr, respectively. In all cases, the enantioselectivity was at or above $98 \%$ ee. A variety of aldimine esters also provided excellent results, including alkyl, benzyl and aryl $\mathrm{R}^{1}$ substituents (24c-24e). Additionally, all four stereoisomers of product $\mathbf{2 4 e}$ were accessed with comparable yields and selectivities by altering the stereochemistry of the Ir and Cu co-catalysts.

Wang demonstrated applications of this method. For instance, plant growth regulator (2S,3S)-2-amino-3cyclopropylbutanoic acid $\mathbf{2 6}$ was synthesized. Imino ester $\mathbf{2 4 f}$ was first constructed using this highly selective synergistic coupling and was then converted to compound 25 via cyclopropanation in $99 \%$ yield. Lastly, cyclopropane $\mathbf{2 5}$ was hydrogenated to the carboxylic acid $\mathbf{2 6}$ in 99\% yield and 10:1 dr with full retention of stereochemistry. These three steps offer highly efficient and selective access to $\mathbf{2 6}$ compared to previously reported 6-8 step syntheses. ${ }^{29,30}$ 

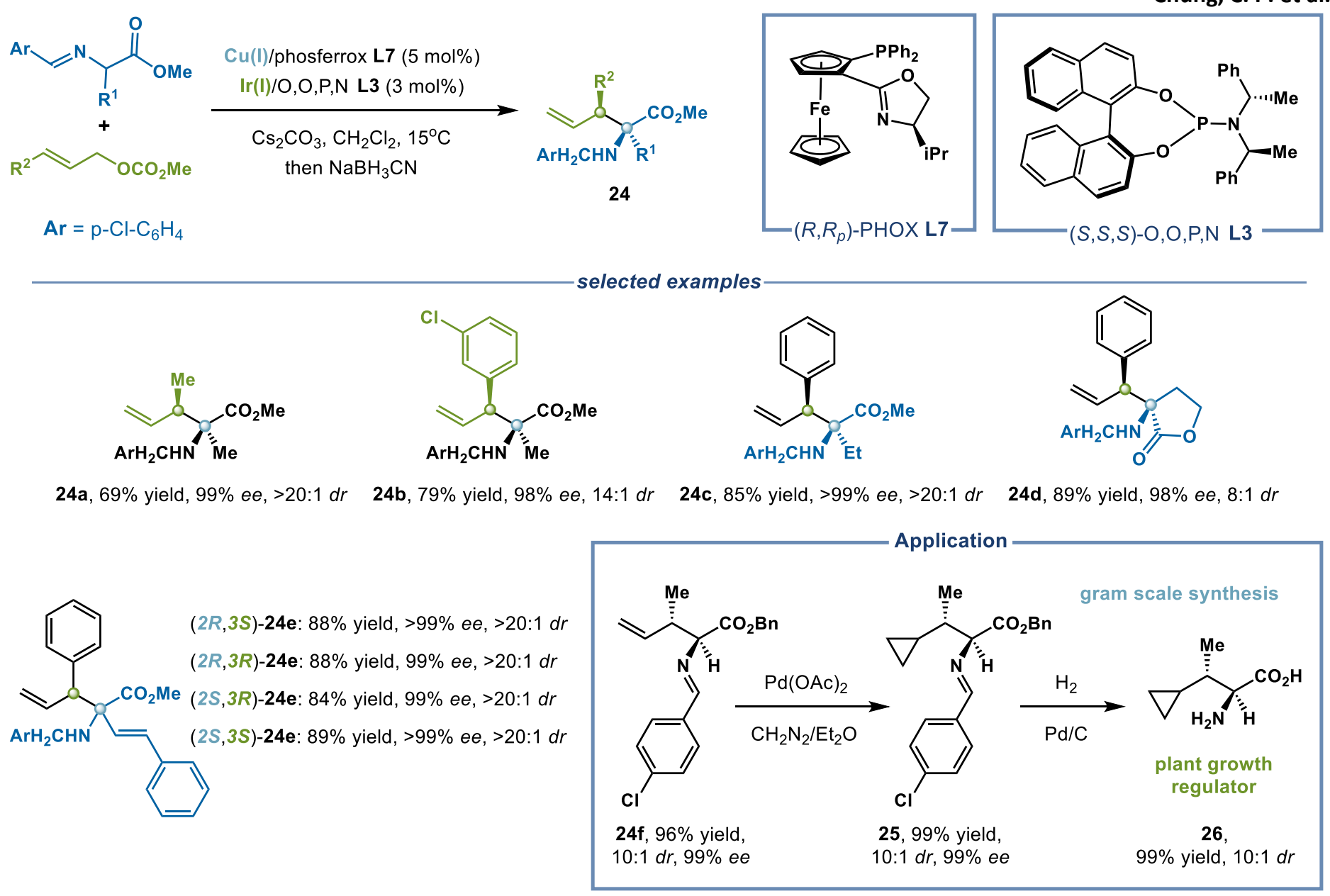

Figure 11. Wang ${ }^{28}$ and co-workers' Ir and Cu dual-catalyzed allylation of aldimine esters.

Next, Zi reported a variation of Zhang's and Wang's works using a Pd and Cu dual catalyst system and 1,3dienes (Figure 12). ${ }^{31}$ In contrast to prior reports, however, a Pd- $\pi$-allyl complex bearing a chiral Josiphos ligand $\mathbf{L 9}$ is formed by the insertion of a 1,3-diene into a $\mathrm{Pd}-\mathrm{H}$ bond. The use of transition-metal hydrides has been effective for coupling of unsaturated motifs such as allenes, alkynes, and 1,3-dienes with various nucleophiles. ${ }^{32-}$ ${ }^{44}$ This $\mathrm{Pd}-\pi$-allyl complex then engages with the $\mathrm{Cu}$-activated aldimine ester to generate the coupled product 27.

The scope of this transformation builds upon the previously reported methods. Firstly, all four stereoisomers of $\mathbf{2 7 a}$ were accessed in $>99 \%$ ee; however, the diastereoselectivities varied for each case, which could be a result of matched-mismatched pairs. Halogen-substituted phenyl dienes (27b), lactams (27d), lactones, and cyclic imine-derived aldimine esters (27e) resulted in high reactivities and selectivities. Moreover, bulkier esters such as $\mathbf{2 7 f}$ gave increased reactivities. Electron-withdrawing and electron-donating phenyl $\mathrm{R}^{4}$ substituents provided good yields as well as excellent diastereo- and enantioselectivities. A few other aromatic and heteroaromatic substituents (2-naphthyl, 2-furyl, and 2-thiophenyl) were also reported to give good yields and high selectivities. The scope was limited by alkyl substituted dienes which gave decreased yields 27c. Additionally, the reaction performs will with the use of ketimine substrates $\mathbf{( 2 7} \mathbf{g})$. In contrast to previous reports, this method allows for the addition of 1,4-disubstituted dienes enabling an expanded scope towards other alkylsubstituted $\beta$-stereocenters (27h, 27i); however, accessing DAAs bearing aryl $\mathrm{R}^{2}$ substituents with this method remains a challenge. 


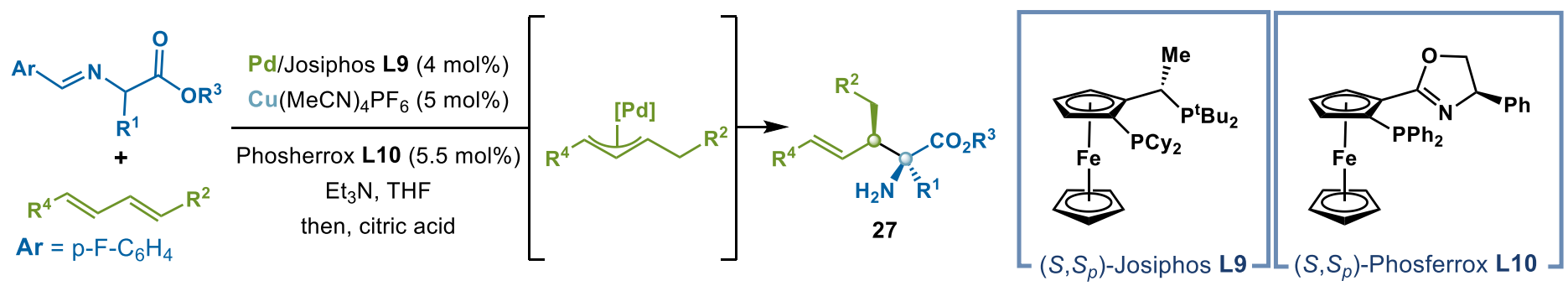

selected examples

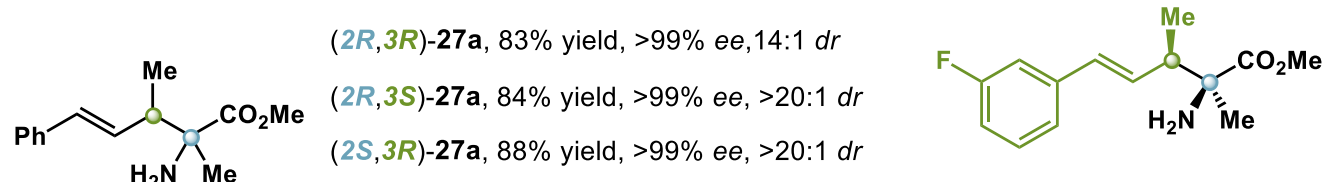

(2S,3S)-27a, 82\% yield, >99\% ee,13.6:1 dr 27b, $82 \%$ yield, $>99 \%$ ee, $>20: 1 d r$<smiles>COC1(C(C)=O)CCC=N1</smiles>

(2S,3R)-27e, $90 \%$ yield, >99\% ee, $>20: 1 d r$

$(2 R, 3 R)-27 e, 93 \%$ yield, $>99 \%$ ee, $13: 1 d r$

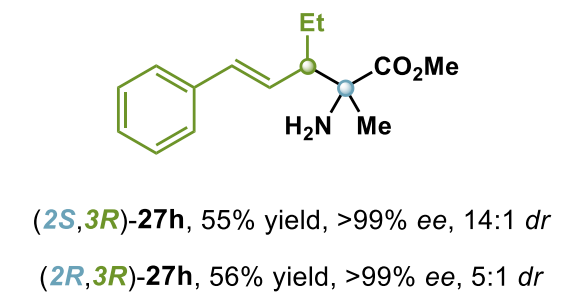

(2S,3R)-27h, 55\% yield, >99\% ee, 14:1 dr $(2 R, 3 R)-27 h, 56 \%$ yield, $>99 \%$ ee, $5: 1 d r$<smiles>CC(=O)OCC/C=C/O[V]([14CH3])(N)OC(C)=O</smiles>

27c, $46 \%$ yield, $>93 \%$ ee, $>20: 1 d r$ 27d, $76 \%$ yield, $>99 \%$ ee, $>20: 1 d r$<smiles>CO/C(=N\C(=C/c1ccccc1)c1ccccc1)OC(C)=O</smiles>

(2S,3R)-27g, 85\% yield, >99\% ee, >20:1 dr $(2 R, 3 R)-\mathbf{2 7 g}, 85 \%$ yield, $>99 \%$ ee, $>20: 1 d r$

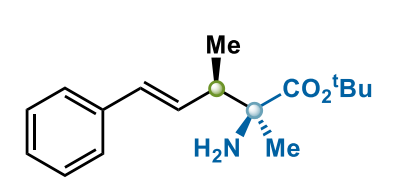

27f, $95 \%$ yield, $>99 \%$ ee, $>20: 1 d r$

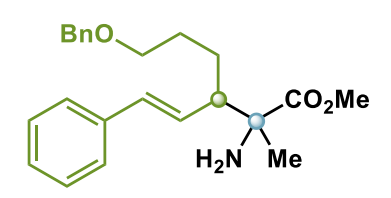

(2S,3R)-27i, 45\% yield, 98\% ee, 10:1 dr $(2 R, 3 R)-27 i, 47 \%$ yield, $97 \%$ ee, $5: 1 d r$

Figure 12. $\mathrm{Zi}^{31}$ and co-workers' Pd and Cu dual-catalyzed coupling of aldimine esters and dienes.

\section{Alkynes as Atom Economical Metal-Allyl Precursors}

As an alternative to allylic carbonates and acetates, transition-metal $\pi$-allyl complexes can also be generated from alkynes. ${ }^{37,45-50}$ Similar atom economical ${ }^{52}$ isomerizations have been used in conjunction with nucleophiles to generate $\mathrm{C}-$ Heteroatom and $\mathrm{C}-\mathrm{C}$ bonds with high enantioselectivities. ${ }^{33-43} \mathrm{Using}$ this method, the branched regioisomer is preferred making this a complementary approach to previous reports by Ooi. ${ }^{44,51}$ This autotandem catalytic process begins with a migratory insertion of alkyne $\mathbf{2 8}$ into Rh-H $\mathbf{2 9}$ to generate intermediate 30. This is followed by $\beta$-hydride elimination to generate allene $\mathbf{3 1}$ (Figure 13). The allene $\mathbf{3 1}$ then undergoes migratory insertion into $\mathrm{Rh}-\mathrm{H} \mathbf{2 9}$ to generate Rh- $\pi$-allyl complex $\mathbf{3 2}$. As before, $\pi$-allyl complex 32 can be intercepted by a nucleophile to generate product 33. 


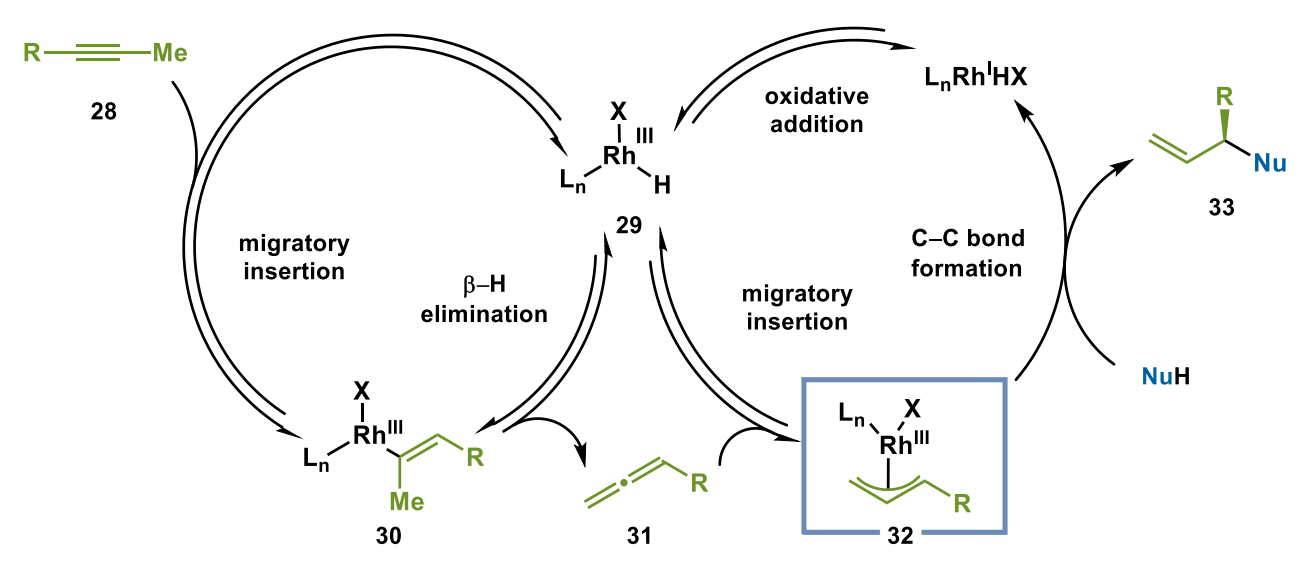

Chung, C. P. et al.

Figure 13. Catalytic cycle for $\mathrm{Rh}-\mathrm{H}$ tandem catalysis.

We envisioned employing this strategy for the asymmetric synthesis of DAA precursors. ${ }^{44}$ An examination of $\alpha$-nitrocarbonyl derivatives indicated $\alpha$-nitroesters as the best coupling partners. These substrates provided high yields and diastereoselectivities as well as high enantioselectivities with the use of MeO-BIPHEP L11 as a chiral ligand (Figure 14). The substrate scope was sensitive to both the sterics and electronics of each coupling partner. In nearly all cases, high diastereo- and regioselectivities (>20:1 $d r$ and $r r$ ) were observed. For $\alpha$ nitroesters derived from the canonical amino acids, sterically hindered side chains such as valine derivative $34 a$ gave no reactivity. Electron poor groups such as para-fluorophenylalanine derivative $\mathbf{3 4 b}$, and tyrosine derivative $\mathbf{3 4 c}$ gave moderate yields but high enantioselectivities. Interestingly, methionine derivative $\mathbf{3 4 d}$ gave excellent enantioselectivity but showed a reduced diastereoselectivity of $6: 1 d r$. Heteroaromatic $\mathrm{R}^{1}$ substituents such as the indole in tryptophan derivative $34 \mathrm{e}$ performed well under the standard conditions. As with valine derivative $\mathbf{3 4 a}$, phenyl substitution at $\mathrm{R}^{1}$ resulted in no reaction $(\mathbf{3 4} \mathrm{g})$. The reaction was more tolerant of steric hindrance for substitutions at $\mathrm{R}^{3}$ (34f). For the scope of alkynes, electron-withdrawing $\mathbf{3 4 h}$ and electrondonating 34i para-substituted phenyl alkynes gave moderate to good yields (56\% to $88 \%$ ) and excellent enantioselectivities ( $90 \%$ ee to $94 \%$ ee). Meta-substituted electron-rich $\mathbf{3 4 k}$ and electron-poor $34 \mathbf{j}$ phenyl alkynes also resulted in good reactivity and selectivity (58\% to $79 \%$ yield, $92 \%$ to $96 \%$ ee). Sterically hindered ortho-chloro-substituted phenyl alkyne $\mathbf{3 4 l}$ as well as 2-naphthyl alkyne $\mathbf{3 4 m}$ gave high enantioselectivities but only moderate yields. Unfortunately, alkyl substituents resulted in no reactivity. Nonetheless, product $\mathbf{3 4 n}$ was efficiently reduced to the protected amino ester $\mathbf{3 5}$ with indium powder. This mild reduction can be performed in the presence of other reductively labile functional groups (i.e., esters and olefins). 
Chung, C. P. et al.

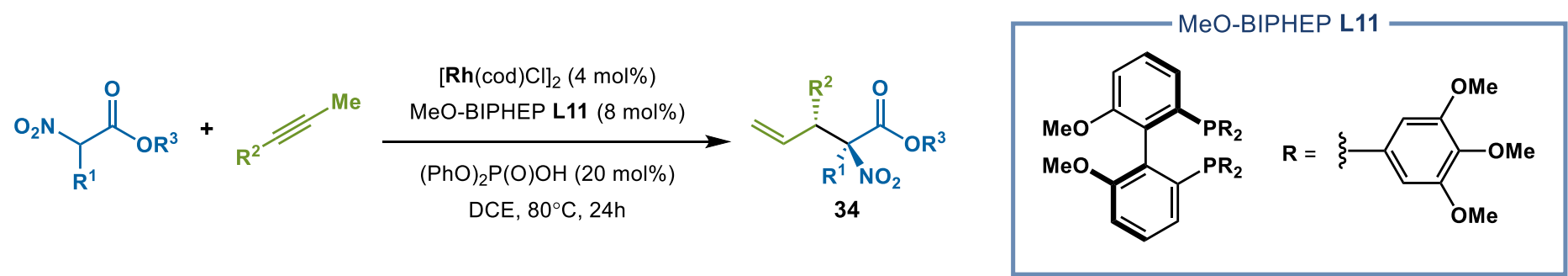

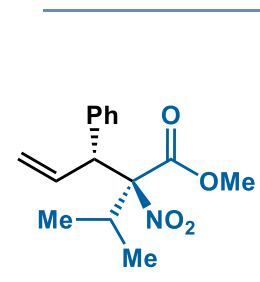

34a, not detected<smiles>C=C[C@H](c1ccccc1)[C@](C)(C(=O)OC1CCCCC1)[N+](=O)[O-]</smiles>

34f, $96 \%$ yield $90 \%$ ee, $>20: 1 d r$

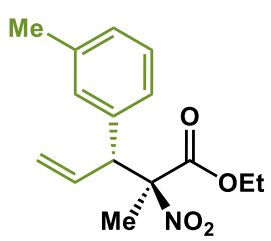

34k, 58\% yield $96 \%$ ee, $20: 1 d r$

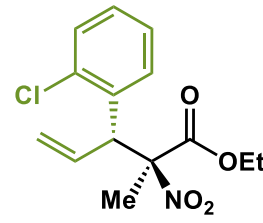

$341,43 \%$ yield $92 \%$ ee, $>20: 1 d r$

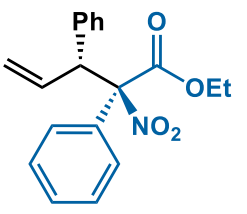

$\mathbf{3 4 g}$, not detected

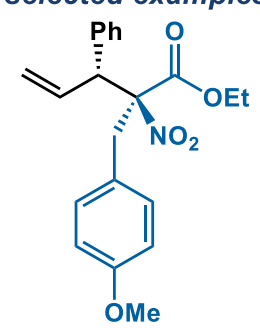

34c, 38\% yield

$96 \%$ ee, $>20: 1 d r$

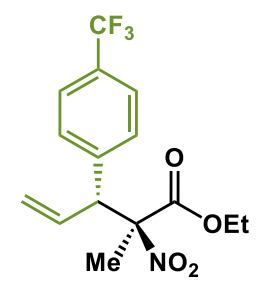

34h, 56\% yield

$90 \%$ ee, $>20: 1 d r$

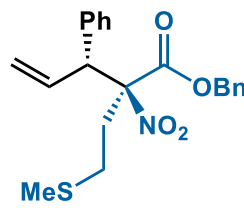

34d, 34\% yield

$94 \%$ ee, $6: 1 d r$

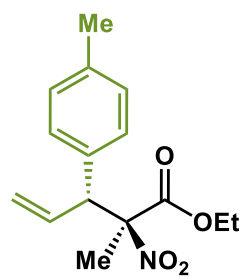

$34 \mathbf{i}, 88 \%$ yield

$94 \%$ ee $,>20: 1 d r$

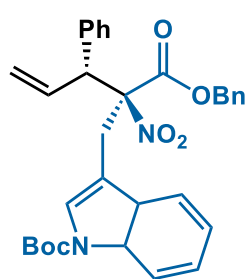

$34 \mathrm{e}, 65 \%$ yield

$96 \%$ ee, $>20: 1 d r$

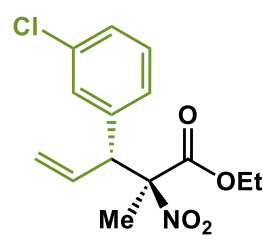

34j, 79\% yield

$92 \%$ ee, $>20: 1 d r$

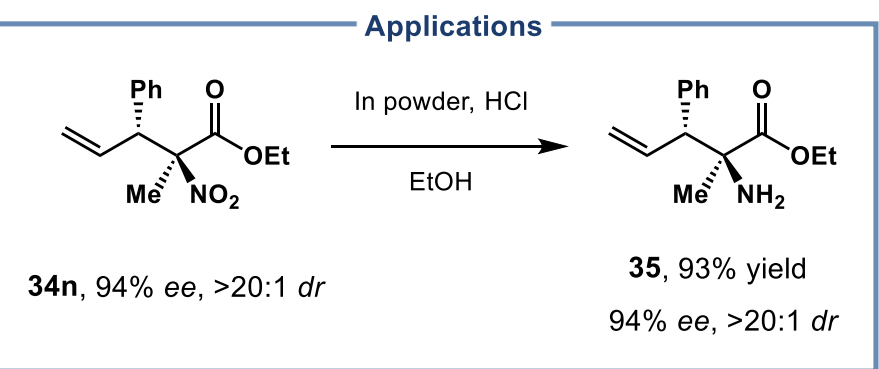

Figure 14. Selected examples from Dong ${ }^{44}$ and co-workers, showing the substrate scope of nitroesters (34a-34g) and alkynes (34h-34m), and applications of the coupled product $\mathbf{3 4 n}$.

We undertook mechanistic studies. Deuterated phenyl alkyne $\mathbf{3 6}$ was coupled with nitroester $\mathbf{3 7}$ to give product 38 (Figure 15). The presence of hydrogen atoms at the $\delta$-position indicates a reversible $\beta$-hydride elimination step. A Rh-H complex was observed by ${ }^{1} \mathrm{H}$ NMR. Lastly, a proper balance between the rates of isomerization and allylation were found to be critical for the transformation's efficiency. When alkyne 28n was replaced with allene 31n, yields were significantly diminished with higher equivalencies of allene 31n. At substoichiometric amounts of allene, however, higher yields could be restored. These results indicated a possible allene intermediate that is likely generated at low concentrations. ${ }^{53-56}$ Moreover, allene 31n polymerizes under the reaction conditions in the absence of nucleophile $\mathbf{3 7}$ indicating a decomposition pathway and supporting the need to control the relative rates of both the isomerization and allylation cycles to maintain high reaction efficiency. 

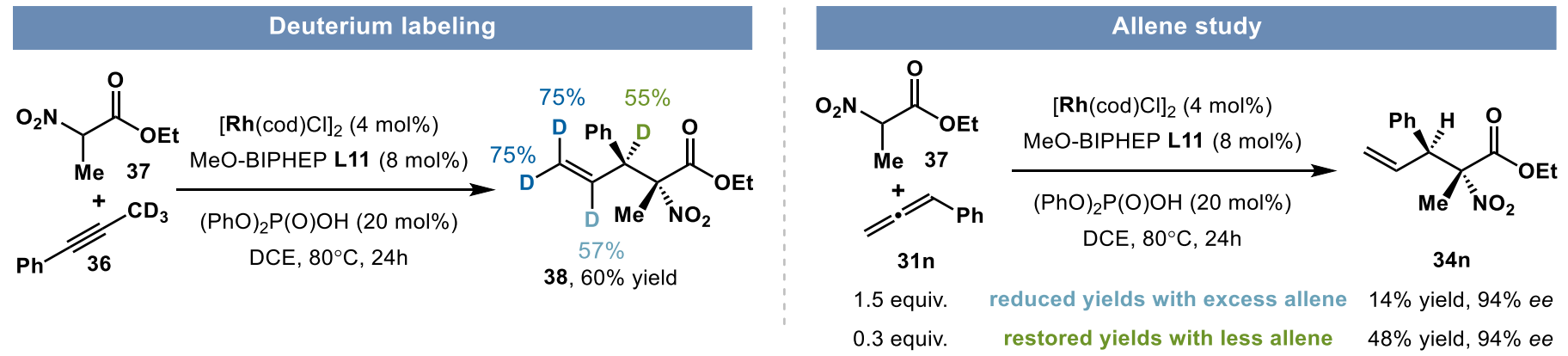

Figure 15. Mechanistic studies support the proposed catalytic cycle.

\section{Conclusions}

The highlighted works in this review offer insights into reaction mechanisms, scope, and versatility for the asymmetric preparation of DAA precursors with consecutive stereocenters. We recently added to this reaction toolbox by demonstrating the isomerization of alkynes with $\mathrm{Rh}-\mathrm{H}$ tandem catalysis. This report provides an acyclic and atom-economical method to prepare these amino acid precursors, opening the door for further exploration to expand the scope and advance applications. Such future efforts could target other biologically relevant motifs such as $\beta$-amino acids.

\section{Acknowledgements}

Funding provided by UC Irvine, the National Institutes of Health (R35GM127071), the National Science Foundation (CHE-1956457), the UC Irvine Undergraduate Research Opportunity Program (UROP), and the ACS DOC Summer Undergraduate Research Fellowship (SURF).

\section{References}

1. Zorn, J. A.; Wells, J. A. Nat Chem Biol. 2010, 6, 179-188.

https://doi.org/10.1038/nchembio.318

2. Bilgicer, B.; Kumar, K. J. Chem. Educ. 2003, 80, 11, 1275-1281.

https://doi.org/10.1021/ed080p1275

3. de Graaf, A. J.; Kooijman, M.; Hennink, W. E.; Mastrobattista, E. Bioconjug. Chem. 2009, 20, 7, $1281-1295$. https://doi.org/10.1021/bc800294a

4. Hodgson, D. R. W.; Sanderson J. M. Chem. Soc. Rev. 2004, 33, 7, 422-430.

https://doi.org/10.1039/b312953p

5. Hohsaka, T.; Sisido, M. Curr Opin Chem Biol. 2002, 6, 6, 809-815.

https://doi.org/10.1016/S1367-5931(02)00376-9

6. Hendrickson, T. L.; de Crécy-Lagard, V.; Schimmel, P. Annu Rev Biochem. 2004, 73, 147-176.

https://doi.org/10.1146/annurev.biochem.73.012803.092429 
7. Young, D. D.; Schultz, P. G. ACS Chem Biol. 2018, 13, 4, 854-870. https://doi.org/10.1021/acschembio.7b00974

8. Tišler, M.; Kolar, P. Advances in Heterocyclic Chemistry 1995, 64, 1-79. https://doi.org/10.1016/S0065-2725(08)60170-1

9. Yamada, S.; Hiroi, K.; Achiwa, K. Tet. Lett. 1969, 48, 4233-4236. https://doi.org/10.1016/S0040-4039(01)88662-7

10. Metrano, A. J.; Miller, S. J. Acc. Chem. Res. 2019, 52, 1, 199-215. https://doi.org/10.1021/acs.accounts.8b00473

11. Colby Davie, E. A.; Mennen, S. M.; Xu, Y.; Miller S. J. Chem. Rev. 2007, 107, 12, 5759-5812. https://doi.org/10.1021/cr068377w

12. Blaskovich, M. A. T. J. Med. Chem. 2016, 59, 24, 10807-10836. https://doi.org/10.1021/acs.jmedchem.6b00319

13. Patil, S.; Zhang, L.; Martenyi, F. et al. Nat . Med. 2007, 13, 1102-1107. https://doi.org/10.1038/nm1632

14. Porter, M. R.; Xiao, H.; Wang, J.; Smith, S. B.; Topczewski, J. J. ACS Med. Chem. Lett. 2019, 10, 10, 14361442. https://doi.org/10.1021/acsmedchemlett.9b00225

15. Acena, J. L.; Sorochinsky, A. E.; Soloshonok, V. A. Synthesis 2012, 44, 1581-1602. https://doi.org/10.1055/s-0031-1289756

16. Pierrot, D.; Marek, I. Angew. Chem. Int. Ed. 2019, 59, 1, 36-49. https://doi.org/10.1002/anie.201903188

17. Trost, B. M.; Dogra, K. J. Am. Chem. Soc. 2002, 124, 25, 7256-7257. https://doi.org/10.1021/ja020290e

18. Chen, W.; Hartwig, J. F. J. Am. Chem. Soc. 2013, 135, 6, 2068-2071. https://doi.org/10.1021/ja311363a

19. Wei, X.; Liu, D.; An, Q.; Zhang, W. Org. Lett. 2015, 17, 23, 5768-5771. https://doi.org/10.1021/acs.orglett.5b02868

20. Zhang, Z.; Xiao, F.; Wu, H.-M.; Dong, X.-Q.; Wang, C.-J. Org. Lett. 2020, 22, 2, 569-574. https://doi.org/10.1021/acs.orglett.9b04341

21. Goldfogel, M. J.; Meek, S. J. Chemical Science 2016, 7, 7, 4079-4084. https://doi.org/10.1039/C5SC04908C

22. Acher, F. C.; Tellier, F. J.; Azerad, R.; Brabet, I. N.; Fagni, L.; Pin, J.-P. R. J. Med. Chem. 1997, 40, 19, 31193129.

https://pubs.acs.org/doi/10.1021/jm970207b

23. Kim, U. B.; Jung, D. J.; Jeon, H. J.; Rathwell, K.; Lee, S.-g. Chem. Rev. 2020, 120, 24, 13382-13433. https://pubs.acs.org/doi/full/10.1021/acs.chemrev.0c00245

24. Allen, A. E.; MacMillan, D. W. C. Chem. Sci., 2012, 3, 633-658. https://doi.org/10.1039/C2SC00907B

25. Su, Y.-L.; Li, Y.-H.; Chen, Y.-G.; Han, Z.-Y. Chem. Commun. 2017, 53, 1985-1988. https://doi.org/10.1039/C6CC09654A

26. Calaza, M. I.; Cativiala, C. Eur. J. Org. Chem. 2008, 20, 3427-3448. https://doi.org/10.1002/ejoc.200800225

27. Huo, X.; Zhang, J.; Fu, J.; He, R.; Zhang, W. J. Am. Chem. Soc. 2018, 140, 6, 2080-2084. https://doi.org/10.1021/jacs.8b00187 
28. Wei, L.; Xu, S.-M.; Chang, X.; Wang, C.-J. J. Am. Chem. Soc. 2018, 140, 4, 1508-1513. https://doi.org/10.1021/jacs.7b12174

29. Morimoto, Y.; Takaishi, M.; Kinoshita, T.; Sakaguchi, K.; Shibata, K. Chem. Commun. 2002, 42-43. https://doi.org/10.1039/b108752e

30. Spangenberg, T.; Schoenfelder, A.; Breit, B.; Mann, A. Org. Lett. 2007, 9, 3881-3884. https://doi.org/10.1021/ol071305m

31. Zhang, Q., Yu, H., Shen, L., Tang, T., Dong, D., Chai, W., Zi, W. J. Am. Chem. Soc. 2019, 141, 37, 1455414559.

https://doi.org/10.1021/jacs.9b07600

32. Wu, Y.; Huo, X.; Zhang, W. Chem. Eur. J. 2019, 26, 22, 4895-4916. https://doi.org/10.1002/chem.201904495

33. Cruz, F. A.; Dong, V. M. J. Am. Chem. Soc. 2017, 139, 1029-1032. https://doi.org/10.1021/jacs.6b10680

34. Cruz, F. A.; Zhu, Y.; Tercenio, Q. D.; Shen, Z.; Dong, V. M. J. Am. Chem. Soc. 2017, 139, 10641-10644. https://doi.org/10.1021/jacs.7b05893

35. Chen, Q.-A.; Cruz, F. A.; Dong, V. M. J. Am. Chem. Soc. 2015, 137, 3157-3160. https://doi.org/10.1021/ja512015w

36. Park, J.-W.; Kang, B.; Dong, V. M. Angew, Chem. Int. Ed. 2018, 57, 13598-13602. https://doi.org/10.1002/anie.201804955

37. Koschker, P.; Breit, B. Acc. Chem. Res. 2016, 49, 8, 1524-1536. https://pubs.acs.org/doi/full/10.1021/acs.accounts.6b00252

38. Haydl, A. M.; Hilpert, L. J.; Breit, B. Chem. Eur. J. 2016, 22, 6547-6551. https://doi.org/10.1002/chem.201601198

39. Berthold, D.; Breit, B. Org. Lett. 2018, 20, 598-601. https://doi.org/10.1021/acs.orglett.7b03708

40. Liu, Z.; Breit, B. Angew. Chem. Int. Ed. 2016, 55, 8440-8443. https://doi.org/10.1002/anie.201603538

41. Koschker, P.; Kähny, M.; Breit, B.; J. Am. Chem. Soc. 2015, 137, 3131-3137. https://doi.org/10.1021/jacs.5b01131

42. Xie, L.; Yang, H.; Ma, M.; Xing, D. Org. Lett. 2020, 22, 2007-2011. https://doi.org/10.1021/acs.orglett.0c00375

43. Ji, D.-W.; Yang, F.; Chen, B.-Z.; Min, X.-T.; Kuai, C.-S.; Hu, Y.-C.; Chen, Q.-A. Chem. Commun. 2020, 56, 84688471.

https://doi.org/10.1039/D0CC04002A

44. Davison, R. T.; Parker, P. D.; Hou, X.; Chung, C. P.; Augustine, S. A.; Dong, V. M. Angew. Chem. Int. Ed. 2021, $60,9,4599-4603$.

https://doi.org/10.1002/anie.202014015

45. Wolf, J.; Werner, H. Organometallics 1987, 6, 1164-1169.

https://doi.org/10.1021/om00149a005

46. Cruz, F. A.; Chen, Z.; Kurtoic, S. I.; Dong, V. M. Chem. Commun., 2016, 52, 5836-5839. https://doi.org/10.1039/C6CC02522F

47. Beck, T. M.; Breit, B. Eur. J. Org. Chem. 2016, 35, 5839-5844.

https://doi.org/10.1002/ejoc.201601230 
48. Li, C.; Grugel, C. P.; Breit, B. Chem. Commun. 2016, 52, 5840-5843. https://doi.org/10.1039/C6CC02272C

49. Beck, T. M.; Breit, B. Org. Lett. 2016, 18, 124-127. https://doi.org/10.1021/acs.orglett.5b03391

50. Zheng, W.-F.; Xu, Q.-J.; Kang, Q. Organometallics 2017, 36, 2323-2330. https://doi.org/10.1021/acs.organomet.7b00284

51. Ohmatsu, K.; Ito, M.; Kunieda, T.; Ooi, T. Nat. Chem. 2012, 4, 473-477. https://doi.org/10.1038/nchem.1311

52. Trost, B. M. Science 1991, 254, 1471-1477. https://doi.org/10.1126/science.1962206

53. Park, B. Y.; Nguyen, K. D.; Chaulagain, M. R.; Komanduri, V.; Krische, M. J. J. Am. Chem. Soc. 2014, 136, 11902-11905. https://doi.org/10.1021/ja505962w

54. Osakada, K.; Choi, J.-C.; Koizumi, T.-a.; Yamaguchi, I.; Yamamoto, T. Organometallics 1995, 14, 4962-4965. https://doi.org/10.1021/om00010a072

55. Takagi, K.; Tomita, I.; Endo, T. Macromolecules 1997, 30, 7386-7390. https://doi.org/10.1021/ma9708959

56. Chen, Q.-A.; Chen, Z.; Dong, V. M.; J. Am. Chem. Soc. 2015, 137, 8392-8395. https://doi.org/10.1021/jacs.5b05200

\section{Authors' Biographies}

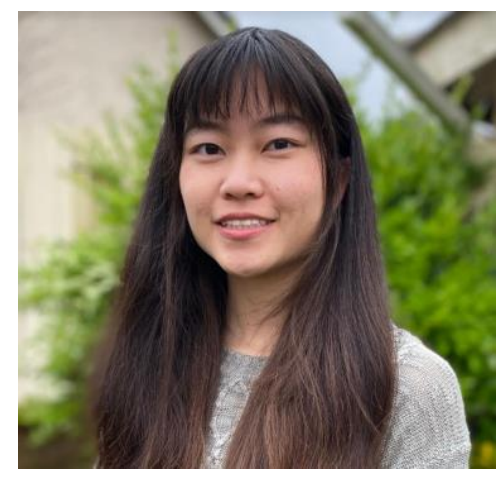

Crystal P. Chung received her Bachelor of Science degree in Chemistry with Synthetic Chemistry specialization from the University of California Irvine. During that time, she studied transition-metal catalysis in the lab of Professor Vy Dong and was the recipient of a 2020 ACS DOC Summer Undergraduate Research Fellowship award. Crystal will soon be pursuing her PhD at the University of Washington in Seattle. 


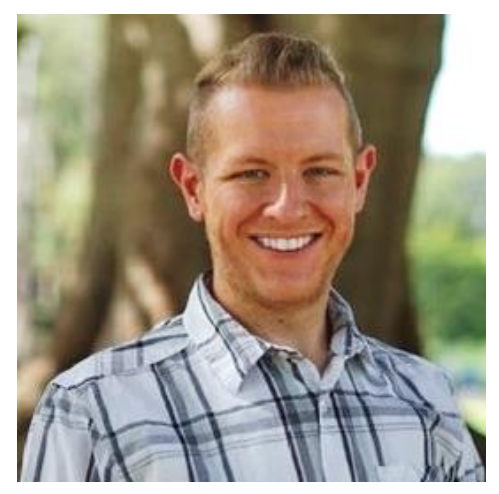

Chung, C. P. et al.

Dr. Patrick D. Parker was born and raised in Nashville, Tennessee. He obtained his Bachelor of Science degree in chemistry and mathematics from Lipscomb University. Patrick received his PhD in chemistry at North Carolina State University with Joshua Pierce and is currently completing his postdoctoral studies with Vy Dong at UC Irvine. He will soon be starting his professional career as a process chemist at Gilead Sciences, Inc.

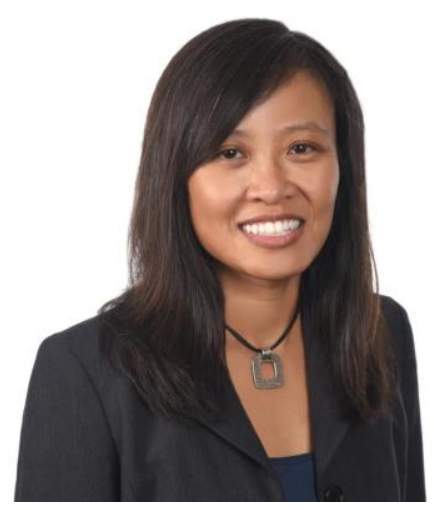

Prof. Vy M. Dong was born in Big Spring, Texas and grew up in Anaheim, California. She graduated from UC Irvine, where she majored in chemistry and completed an honor's project with Larry Overman. Vy obtained her PhD from Caltech with David MacMillan and completed postdoctoral studies with Robert Bergman and Ken Raymond at UC Berkeley. She began her independent career at the University of Toronto and returned to UC Irvine as a full professor in 2012. The Dong research team is interested in developing new catalysts, methods, and reagents for organic synthesis. 